\title{
Molecular, Behavioral, and Physiological Consequences of Methamphetamine Neurotoxicity: Implications for Treatment
}

\author{
Anna Moszczynska and Sean Patrick Callan \\ Department of Pharmaceutical Sciences, Eugene Applebaum College of Pharmacy and Health Sciences, Wayne State \\ University, Detroit, Michigan
}

Received October 22, 2016; accepted May 9, 2017

\section{ABSTRACT}

Understanding the relationship between the molecular mechanisms underlying neurotoxicity of high-dose methamphetamine $(\mathrm{METH})$ and related clinical manifestations is imperative for providing more effective treatments for human METH users. This article provides an overview of clinical manifestations of METH neurotoxicity to the central nervous system and neurobiology underlying the consequences of administration of neurotoxic METH doses, and discusses implications of METH neurotoxicity for treatment of human abusers of the drug.

\section{Introduction}

Methamphetamine (METH) is a central nervous system stimulant, chronic abuse of which continues to be a significant problem in the United States and worldwide. METH has powerful addictive properties and, therefore, has devastating effects on health and other aspects of life of the people who abuse it. METH is a schedule II drug, which can only be prescribed for attention deficit hyperactivity disorder (ADHD), extreme obesity, or narcolepsy (as Desoxyn; Recordati Rare Diseases LLC, Lebanon, NJ), with amphetamine being prescribed more often for these conditions due to amphetamine having lower reinforcing potential than METH (Lile et al., 2013). Even though amphetamine is less potent than METH, it can also be neurotoxic when taken at high doses, and it has the same molecular mechanisms of action as METH. Molecular mechanisms underlying neurotoxicity of amphetamine and METH are complex, and they ultimately lead to severe dysfunction of dopaminergic (DAergic) and, in most species, serotonergic (5HTergic) neurotransmission. There is no treatment for some neurologic complications associated with chronic METH use, such as cognitive impairments.

Understanding the relationship between the molecular mechanisms underlying neurotoxicity of METH and related clinical manifestations may help to develop pharmacological

https://doi.org/10.1124/jpet.116.238501. treatment of neurologic impairments associated with METH use, as well as improve therapies aimed at METH dependence and relapse.

\section{Prevalence of METH Abuse}

Per the 2015 report form the United Nations Office on Drugs and Crime, METH dominates the global market for synthetic drugs (UNODC, 2015). Thus, METH confiscations grew 1.5fold from 34 tons in 2009 to 88 tons in 2013. In recent years, METH abuse increased dramatically in east and southeast Asia, but not in North America. The number of METH users in the United States has been stable in most states among 12-64year-olds between 2008 and 2014 . Approximately $0.3 \%$ of the U.S. population used amphetamines chronically between 2008 and 2014. Nevertheless, increases in METH abuse have been reported in Minnesota, Ohio, and California. In 2015, approximately 897,000 people were current users of METH in the United States (Substance Abuse and Mental Health Services Administration, 2016).

\section{Medical Use of METH}

METH is a methylated amphetamine that is more potent in the central nervous system (CNS) than amphetamine, likely due to the addition of the methyl group (Lake and Quirk, 1984) and a consequent higher lipophilicity (Gulaboski et al., 2007).

ABBREVIATIONS: 5HT, serotonin receptor; 5HTergic, serotonergic; ADHD, attention hyperactivity disorder; CNS, central nervous system; DA, dopamine; DAergic, dopaminergic; DAT, dopamine transporter; GLU, glutamate; GLUergic, glutamatergic; METH, methamphetamine; NE, noradrenaline; NEergic, Noradrenergic; PD, Parkinson's disease; PET, positron emission tomography; PFC, prefrontal cortex; SERT, serotonin transporter; TPH, tryptophan hydroxylase; TH, tyrosine hydroxylase; VMAT2, vesicular monoamine transporter 2; ZSET1446, spiro[imidazo[1,2-a]pyridine3,2-indan]-2(3H)-one. 
The half-life of METH in humans is between 9 and 12 hours, depending on route of administration (Cook et al., 1992, 1993), with oral METH having the shortest half-life and intravenous METH having the longest. The general pharmacodynamic effects of different types of amphetamines are similar, and indeed, humans trained to discriminate $\mathrm{METH}$ will respond to $d$-amphetamine; however, $d$-amphetamine does not produce the alterations to blood pressure and heart rate to the degree observed with METH (Sevak et al., 2009). Likewise, human self-reported subjective effects of METH and amphetamine are similar, although METH is typically rated as producing a larger "high" (Kirkpatrick et al., 2012). This is possibly due to METH having a higher lipophilicity and higher ability to release dopamine (DA) via the dopamine transporter (DAT) and inhibit DA uptake compared to amphetamine (Gulaboski et al., 2007; Goodwin et al., 2009). Amphetamine is a metabolite of METH, produced via $N$-demethylation of METH by the CYP2D6 enzyme (Lin et al., 1997). The half-lives of amphetamines vary widely depending on both the isoform and the route of administration. The elimination half-life of amphetamine is reported to be between 15 and 25 hours, whereas the elimination half-life for METH is reported to be between 9 and 15 hours (Mendelson et al., 2006) [reviewed by Carvalho et al. (2012)].

Both amphetamines have two active optic isoforms, $d$-enantiomer and $l$-enantiomer (Hensley and Cody, 1999), with similar pharmacokinetics in humans (Mendelson et al., 2006). At high doses, intoxication produced by METH is similar for both enantiomers; however, the psychodynamic effects of $l$-METH are shorter-lived than those of $d$-METH (Mendelson et al., 2006), and are therefore less desired by human users of the drug. In rodents, $d$-enantiomers of both amphetamines produced greater central stimulant effects than $l$-METH due to a higher potency to release DA (Heikkila et al., 1975; Jackson et al., 1975; Kuczenski et al., 1995; Easton et al., 2007). Interestingly, Easton et al. (2007) found that areas mediating pleasurable effects in the rat brain differ for each amphetamine isomer. In addition, $d$-amphetamine is a more potent agonist of the TAAR1 receptor (which regulates DAergic neurotransmission; Miller, 2011) than $l$-amphetamine (Lewin et al., 2011). These findings could explain the stronger reinforcing properties of $d$-isomer compared to $l$-isomer. Unsurprisingly, animals self-administer $d$ - amphetamine at a higher rate than $l$-amphetamine (Balster and Schuster, 1973), indicating that the stronger CNS effects extend to abuse potential.

There is evidence for the $l$-isomer of METH or amphetamine contributing more to the peripheral effects (e.g., heart rate) with $d$-isomer contributing more to the CNS effects (e.g., euphoria) (Smith, 1979; Goodman et al., 2001). There is also evidence to the contrary (Mendelson et al., 2006). The $d$ - and $l$-isomer peripheral effects may vary with the doses administered. $l$-Amphetamine was reported as either as potent or more potent than $d$-amphetamine as a releaser of noradrenaline (NE) in vivo (Heikkila et al., 1975; Easton et al., 2007). Noradrenergic (NEergic) fibers originate in the parabrachial area and project to the pons and medulla oblongata, which could explain the aforementioned finding because these CNS regions are involved in autonomic functions, such as breathing and heart rate. Amphetamines may also activate $\alpha$-adrenergic receptors by releasing NE from the peripheral sympathetic terminal.
As mentioned previously, amphetamines are prescribed for ADHD, narcolepsy, and severe obesity. Their therapeutic doses range from 5 to $60 \mathrm{mg} /$ day (usually in divided doses) and come as $d$-enantiomer or a mixture of the two, $d$ - and $l$-isomers. As discussed earlier, the $d$-enantiomer has stronger CNS effects but is metabolized more quickly than the $l$-enantiomer, which is longer lasting due to the slower breakdown (Cody et al., 2003). As a result, drugs that contain $d$-/l-mixture (e.g., Adderall; Teva Pharmaceuticals USA, Inc, North Wales, PA) were reported to result in better clinical response in some children with ADHD (Patrick et al., 2009). The initial strong central effect of Adderall comes from the $d$-enantiomer, whereas the prolonged effect is provided by $l$-enantiomer (Cody et al., 2003). This allows a patient to take the medication less frequently than a medication containing $d$-amphetamine only (e.g., Dexedrine; Amedra Pharmaceuticals, Horsham, PA). The maximum therapeutic dose is $60 \mathrm{mg}$ of $d$-amphetamine (equivalent to $\sim 120 \mathrm{mg}$ of "pure" illicit amphetamine, which is usually an equal mix of two stereoisomers), but even therapeutic doses can give rise to negative side effects, such as insomnia, loss of appetite, and anxiety (Medscape.com).

$l$-METH, a vasoconstrictor, is the active constituent of the Vicks Inhaler decongestant (Proctor \& Gamble, Cincinnati, $\mathrm{OH}$ ), an over-the-counter product containing about $50 \mathrm{mg}$ of the drug (Smith et al., 2014). Desoxyn, which is $d$-METH, is rarely medically prescribed due to its strong reinforcing properties. Therapeutic doses of Desoxyn are 20-25 mg daily, taken every 12 hours, with dosing not exceeding $60 \mathrm{mg} / \mathrm{day}$ (Medscape.com).

\section{Behavioral and Physiologic Effects of METH}

Short-Term Behavioral and Physiologic Effects of METH: Dose Dependence. DA and serotonin receptor (5HT) pathways regulate a variety of functions and behaviors. Consequently, due to the repeated release of these monoamines in the CNS, METH is responsible for several neurologic problems in METH users. There is clear evidence for a dose-dependent pharmacodynamic profile (Nash and Yamamoto, 1992; Boireau et al., 1995; Wallace et al., 1999), with higher doses of METH resulting in more severe and deleterious consequences brought on by disruption of these pathways. For example, chronic or high-dose METH exposure can lead to the development of psychotic features (Bell, 1973), likely due to excessive DAergic activity (Hsieh et al., 2014). Dysregulation of glutamatergic (GLUergic), GABAergic, cholinergic, and opioidergic signaling by neurotoxic METH doses contributes to other symptoms in a dose-dependent manner (Seiden and Sabol, 1996; Courtney and Ray, 2014; Moratalla et al., 2015), including aggression, depression, motor impairments, and sleep disruption.

Short-term behavioral effects of METH and amphetamine at low to moderate doses include euphoria, "rush," alertness, wakefulness, antifatigue effect, increased confidence, hyperactivity, and loss of appetite (Comer et al., 2001; Mendelson et al., 2006; Pike et al., 2016). Higher doses will also cause talkativeness, aggressiveness, restlessness, and repetitive behavior (Hart et al., 2008). Consumption of METH at very high doses (e.g., in a binge) will trigger the appearance of some or all of the following symptoms: agitation, confusion, anxiety, irritability, dysphoria, violent behavior, impairment of psychomotor and cognitive skills, stereotypy (punding), auditory 
hallucinations, panic, formication (delusions of parasites or insects on the skin), and paranoia (Richards et al., 1999a; Zweben et al., 2004). During the end stage of a METH binge, known as "tweaking," euphoria is gradually replaced by negative feelings (e.g., anxiety, feelings of emptiness) and the appearance of most or all of the symptoms described earlier (Newton et al., 2005). A "crash" phase, synonymous with early withdrawal, which follows METH binge, is characterized by intense fatigue, uncontrollable sleepiness, and catnapping (Gossop et al., 1982).

Short-term physiologic effects of METH and amphetamine include loss of appetite, increased heart rate, blood pressure, and breathing rate, as well as dilation of the pupils and raised body temperature. At higher doses, fever, sweating, headache, blurred vision, dizziness, stomach cramps, muscle fatigue and cramps, chest pains and shaking, dehydration, nausea, and vomiting can occur. Very high doses induce a variety of negative effects, such as hyperthermia; hypertension; cardiac arrhythmia; seizures; cerebral hemorrhage; ischemic infarct; renal failure; rhabdomyolysis; and wakefulness to the point of collapse and temporary blindness, coma, or death (Richards et al., 1999a,b; Mendelson et al., 2006; Cloutier et al., 2013; Jones and Rayner, 2015; Nakagawa et al., 2015).

Long-Term Behavioral and Physiologic Effects of METH: Dose Dependence. Medically prescribed doses of METH have some of the adverse effects described earlier (e.g., dysphoria, insomnia, tremors) and can lead to drug addiction due to the pleasurable effects. Even the lowest dose ( $5 \mathrm{mg} ; 0.06-0.08 \mathrm{mg} / \mathrm{kg}$ ) is capable of resulting in reinforcing drug effects in patients (Hart et al., 2001).

Humans abuse METH in different patterns (once a week, once a day, in a binge) and by different routes of administration (oral, intranasal, intravenous) (Cook et al., 1993; Mirecki et al., 2004; Newton et al., 2005). Doses of recreationally taken METH are estimated to be between 20 and $40 \mathrm{mg}$, which are equal to $0.25-0.67-\mathrm{mg} / \mathrm{kg}$ doses for $60-80-\mathrm{kg}$ persons. A report from the U.S. National Highway Traffic Safety Administration states that "purity of METH is currently very high, at 60-90\%," i.e., the illicit METH is predominantly $d$-METH, and that "common abused doses are 100-1000 mg/day, and up to $5000 \mathrm{mg} / \mathrm{day}$ in chronic binge use." The results from several surveys and research studies on chronic METH abuse within the United States agree with this report; on average, selfreported chronic METH use was $0.25-1.6 \mathrm{~g} /$ day (Volkow et al., 2001c, 2015; Chang et al., 2007).

Chronic METH abuse, particularly at high doses, has a variety of cardiovascular, gastrointestinal, neurologic, and physiologic effects, which resemble acute effects of high-dose METH (Perez-Reyes et al., 1991; Mendelson et al., 2006). The latter include cerebral vasculitis as well as intracerebral, subarachnoid, or intracranial hemorrhage. Behavioral consequences of chronic METH use include dependence on the drug, cognitive impairments, anxiety or depression, violent behavior (often risk-taking), insomnia, repetitive movements (stereotypy), and psychosis. Cognitive impairments, disturbed sleep or insomnia, depression, anxiety, and intense drug craving are the most prominent symptoms of METH withdrawal (Zweben et al., 2004; McGregor et al., 2005). Depression and anxiety in withdrawn METH users can lead to suicidal thoughts. These neurologic effects can come directly from neuronal alteration and/or damage (London et al., 2004), and there is evidence that some METH withdrawal symptoms can be remediated by pharmacotherapy (Mizoguchi and Yamada, 2011). In addition, chronic METH users may be at higher risk for developing Parkinson's disease (PD) than nonusers due to the toxic effects of the drug in the nigrostriatal DA pathway (Garwood et al., 2006; Callaghan et al., 2010; Curtin et al., 2015; Todd et al., 2016). Thus, evidence suggests that METH users show a higher risk of later PD diagnosis than matched controls or matched cocaine users, suggesting a strong link between METH toxicity and later PD diagnosis that is not generalized to other psychostimulants (Callaghan et al., 2012).

\section{Pharmacology of METH}

METH is an indirectly acting sympathomimetic amine. It releases DA, 5HT, noradrenaline, and adrenaline from nerve terminals in the central and peripheral nervous system, thus increasing their neurotransmission. Due to high lipophilicity, METH easily crosses the blood-brain barrier and distributes throughout the brain (Kalasinsky et al., 2001). Due to a chemical structure similar to monoamines, METH is recognized as a substrate by DA, 5HT, and noradrenaline plasma membrane transporters in the brain and transported into neurons and neuronal terminals (Zaczek et al., 1991; Fleckenstein et al., 1997; Volz et al., 2007; Yamamoto et al., 2010). Higher concentrations of METH can cross the membranes via passive diffusion (Mack and Bönisch, 1979). It is hypothesized that, once in the monoaminergic terminals, METH acts on the monoamine storage vesicles and depletes them of neurotransmitters by reversing the vesicular monoamine transporter 2 (VMAT2) and collapsing the $\mathrm{pH}$ gradient across the vesicular membrane (Sulzer and Rayport, 1990; Sulzer et al., 1995; Brown et al., 2000). In addition, METH inhibits monoamine metabolism via inhibition of monoamine oxidase (Suzuki et al., 1980; Egashira and Yamanaka, 1993; Santillo, 2014). The net result of these actions is an increase in intracellular levels of cytoplasmic DA and other monoamines. Low $\mathrm{pH}$ within the DA storage vesicles keeps DA from autoxidation. METH also inhibits and triggers a reversal of the monoamine transporters, leading to massive release of monoamines into the synaptic cleft (Volz et al., 2007; Yamamoto et al., 2010). The net result of this METH action is overstimulation of the monoaminergic pathways in the central and peripheral nervous system that can lead to severe dysfunction or even neuronal degeneration in several brain areas, including the striatum, prefrontal cortex (PFC), and hippocampus (Volz et al., 2007; Yamamoto et al., 2010). In addition, acting via the striato-nigro-thalamo-cortical loop, METH triggers an increase in glutamate (GLU) in the striatum, which results in excitotoxicity at higher doses of the drug (Mark et al., 2004). METH has a minimal effect as an agonist at postsynaptic DA receptors and activates them indirectly via released DA. In addition to damaging DAergic and serotonergic terminals, METH also damages cell bodies in the striatum and a few other brain areas (Cadet et al., 2003) [reviewed by Moratalla et al. (2015)].

\section{METH Neurotoxicity in the CNS}

\section{What Is Neurotoxicity?}

Neurotoxicity is most often defined as actual physical damage to neurons. Neurotoxicity can be more broadly defined 
as a permanent or reversible adverse effect of a substance on neuronal structure or function (definition used by the Environment Protection Agency for regulatory purposes), causing loss of neuronal components, loss of entire neurons, histologic signs of neuronal damage, and/or behavioral abnormalities. Consequently, throughout this review, we include under this term neuronal degeneration/damage and alterations in neuronal structure, morphology, and function. Available animal and human data critically evaluated by Kish et al. (2017) indicate that, although medium to high doses of METH damage DAergic and 5HTergic neurons in experimental animals, recreational use of METH does not appear to damage (degenerate) these neurons in humans. However, some human METH users suffer from persistent DA deficits as well as brain structural and metabolic abnormalities (Cadet et al., 2003; Chang et al., 2007; Berman et al., 2008; Hall et al., 2015) as well as persistent mild cognitive impairments (Scott et al., 2007; Dean et al., 2013). In experimental animals, METH neurotoxicity is dose-dependent (Seiden and Sabol, 1996), whereas in humans, there is no clear correlation between total METH consumed and cognitive impairments (discussed later). This, however, may be due to a variety of confounding factors that are characteristic of studies in humans. Recovery of monoaminergic markers does not exclude a possibility of degeneration of monoaminergic pathways, as such damage may increase synthesis of monoaminergic markers and upregulation of function of monoaminergic signaling, as observed in PD (Brotchie and Fitzer-Attas, 2009). These adaptive modifications (e.g., axonal sprouting) may result in abnormal functioning of neurons (Arkadir et al., 2014).

\section{Clinical Manifestations of METH Neurotoxicity}

There are numerous manifestations of METH neurotoxicity in the CNS, including cognitive and psychomotor impairments as well as mental illnesses. Per meta-analytic summary of 17 cross-sectional studies, the most common cognitive impairments in abstinent chronic METH users are impairments in episodic memory, executive function, language skills, and visuoconstructional abilities as well as decreased speed of information processing (Scott et al., 2007). Specifically, learning, executive function, and memory appear to be the most consistently impaired, followed by attention/working memory and overall motor function, whereas visuoconstruction impairments are inconsistently reported in the literature (Scott et al., 2007). In addition to the impairments reported earlier, the meta-analysis revealed that chronic METH users also display impairments in fine motor skills. Another metaanalysis identified three regions of significant gray-matter reduction in the temporal, frontal, and parietal cortex, as well as in the putamen in METH-dependent individuals as compared with healthy controls (Hall et al., 2015). The findings from several qualitative studies were mixed and sometimes contradictory (Nordahl et al., 2003; Cherner et al., 2010; Hart et al., 2012; Dean et al., 2013) but overall suggested that chronic METH abuse causes a cognitive decline. Motor deficits in METH users typically do not involve alterations in gross motor skills (Moszczynska et al., 2004); however, impaired gait (Volkow et al., 2001d) and increased risk for developing PD have been reported (Callaghan et al., 2010, 2012; Curtin et al., 2015; Todd et al., 2016). Other motor impairments include stereotypic behavior, choreoathetoid movements, and dyskinesias that, in some cases, can persist for a long time after cessation of METH use (Rylander, 1972; Lundh and Tunving, 1981; Sperling and Horowitz, 1994; Morgan et al., 2004). Mental illnesses that can persist after cessation of chronic METH use include anxiety, depression, and psychosis (Tong et al., 2014). Psychosis develops more readily in drug users taking METH in high doses and for long periods of time; therefore, it is regarded as a direct consequence of METH neurotoxicity by some scientists. Indeed, METH psychosis is related to the severity of other cognitive impairments, further suggesting that it is a manifestation of METH toxicity (Chen et al., 2015). An alternative hypothesis regarding METH-induced psychosis states that METH use triggers underlying psychosis or schizophrenia. In fact, the symptoms of METH-induced psychosis are similar to those observed in patients with schizophrenia (Zweben et al., 2004; McKetin et al., 2006). Of note, formication is one of the specific manifestations of METH-induced paranoia or psychosis.

\section{Molecular Mechanisms and Loci of METH Neurotoxicity}

METH Neurotoxicity to DAergic and 5HTergic Terminals in Experimental Animals. As previously mentioned, METH enters DAergic terminals via the DAT and passive diffusion, and releases DA from the storage vesicles. Once in the cytoplasm, DA quickly autoxidizes, an event followed by the formation of several reactive oxygen species and DA quinones (Graham et al., 2008). These species trigger oxidative stress and damage to protein and lipid components within the DAergic terminals (Yamamoto and Zhu, 1998; Fitzmaurice et al., 2006; Park et al., 2006; Moszczynska and Yamamoto, 2011). The molecular mechanism(s) underlying METH neurotoxicity to 5HTergic terminals is not clear but is known to depend on DA (Johnson et al., 1987; Gross et al., 2011). METH-induced biochemical and structural changes in striatal monoaminergic terminals are dependent on normal DAergic functions. Specifically, DA $D_{1}$ and $D_{2}$ receptor antagonists were shown to attenuate the toxic effects of METH on DA and 5HT systems (Sonsalla et al., 1986; Xu et al., 2005). In addition to increasing DA, 5HT, and NE, METH induces increased release of GLU in the striatum and other brain areas (Nash and Yamamoto, 1992; Rocher and Gardier, 2001), which contributes to the toxicity of the drug via the excitotoxic pathway (Mark et al., 2004). Additional molecular mechanisms contributing to monoaminergic terminal degeneration are hyperthermia, mitochondrial dysfunction, inflammatory response, ubiquitin-proteasome system impairment, and impairment of axonal transport (Ali et al., 1994; Moszczynska and Yamamoto, 2011; Killinger and Moszczynska, 2016) [reviewed by Cadet et al. (2003); Yamamoto et al. (2010)].

In rats and nonhuman primates, high doses of binge or chronic METH cause selective degeneration of DAergic terminals in the striatum (Hotchkiss and Gibb, 1980; Ricaurte et al., 1982; Woolverton et al., 1989; Moszczynska et al., 1998; Harvey et al., 2000a) while sparing NEergic terminals (Wagner et al., 1980). METH damages DAergic terminals primarily in the striatum, whereas DAergic terminals in the PFC, hippocampus, olfactory bulb, hypothalamus, thalamus, perirhinal cortex, amygdala, and nucleus accumbens are minimally affected or unaffected (Morgan and Gibb, 1980; Ricaurte et al., 1980; Wagner et al., 1980; Eisch et al., 1992; 
Broening et al., 1997; Harvey et al., 2000a; Guilarte et al., 2003; Anderson and Itzhak, 2006; Granado et al., 2010; Chuang et al., 2011). In contrast to DA terminals, 5HT terminals in various brain regions, including the hippocampus, PFC, amygdala, and striatum, are similarly sensitive to the toxic effects of METH (Morgan and Gibb, 1980; Ricaurte et al., 1980; Seiden et al., 1988). METH-induced changes in the hippocampus and PFC are particularly important given their role in learning, memory, and executive functioning.

At the molecular level, METH neurotoxicity to DAergic and 5 HTergic terminals is manifested by persistent (long lasting after METH cessation) reductions in DAergic and 5HTergic markers [DA, 5HT, and their metabolites; DATs and serotonin transporters (SERTs); VMAT2; tyrosine hydroxylase (TH); and tryptophan hydroxylase (TPH)] (Wagner et al., 1980; Preston et al., 1985; Sonsalla et al., 1986; Mooney et al., 1994; Broening et al., 1997; Harvey et al., 2000b), morphologic and structural abnormalities (e.g., swollen axons) (Lorez, 1981; Ricaurte et al., 1982; Sharma and Kiyatkin, 2009), as well as microglial activation and gliosis (Pu et al., 1994; Thomas et al., 2004). It is worth noting that the effect of METH exposure in rodents depends partly on the pattern of exposure. Binge exposure typically results in more severe or longer-lasting effects (including reductions in DAergic function) than a chronic model (Keller et al., 2011; Kesby et al., 2017) of comparable cumulative dose, suggesting development of tolerance to METH toxic effects. To some extent, the loss of DAT, TH, DA, and DA's metabolites is due to a physical loss of axons (Bowyer and Schmued, 2006). However, extended abstinence from METH results in recovery of these DAergic markers in experimental animals and humans (Bowyer et al., 1992; Friedman et al., 1998; Cass and Manning, 1999; Harvey et al., 2000b; Volkow et al., 2001c, 2015), suggesting compensatory changes within the nigrostriatal DA pathway.

METH Neurotoxicity to Neuronal Perikarya in Experimental Animals. In rats and nonhuman primates, METH appears to spare DA cell bodies in the substantia nigra pars compacta from which they originate (Hotchkiss and Gibb, 1980; Ricaurte et al., 1982; Woolverton et al., 1989; Moszczynska et al., 1998; Harvey et al., 2000a, 2009). In mice, DA neurons of the substantia nigra pars compacta degenerate (Deng et al., 2001; Zhu et al., 2005; Ares-Santos et al., 2014), as do multiple other brain areas (Yu et al., 2004; Xu et al., 2005). Administration of high METH doses can also result in toxicity to neuronal, or glial, perikarya in the striatum, parietal cortex, and amygdala, which are GABAergic, cholinergic, and/or GLUergic neurons (Pu et al., 1994; Jayanthi et al., 2004; Xu et al., 2005; Kuczenski et al., 2007; Simões et al., 2007; Beauvais et al., 2011; Fujikawa et al., 2016; Thanos et al., 2016). METH toxicity in cell bodies is manifested by the presence of apoptosis and necrosis, astrocyte or microglia activation, as well as abnormal alterations in cell morphology or structure. METH-induced apoptosis of striatal GABA neurons and frontal cortical neurons depends on GLU and DA and involves mitochondrial dysfunction, endoplasmic reticulum stress, and calcium-influx activation of the calpain pathway (Deng et al., 2001; Jayanthi et al., 2004; Warren et al., 2005, 2007; Tokunaga et al., 2008; Gold et al., 2009; Beauvais et al., 2011; Shiba et al., 2011). In the hippocampus, in addition to inducing apoptosis, which is often followed by blebbing of pyramidal neuron dendrites and death of pyramidal neurons and granular cells, METH inhibits neurogenesis and reduces hippocampal volume (Teuchert-Noodt et al., 2000; Deng et al., 2001; Thompson et al., 2004; Kuczenski et al., 2007; Mandyam et al., 2008; Kochman et al., 2009; Hori et al., 2010). The cortical damage produced by METH occurs via an excitotoxic mechanism (Eisch et al., 1996). METHinduced glial cell death is mediated via oxidative stress and the mitochondrial damage pathway (Stadlin et al., 1998; Jumnongprakhon et al., 2014).

Cognitive Impairments in Experimental Animals. A common animal model of METH toxicity is the binge-exposure model. Animals exposed to single-day high-dose exposure paradigms show a host of behavioral abnormalities, including object (Schröder et al., 2003; Belcher et al., 2005; He et al., 2006; Herring et al., 2008; Siegel et al., 2010) and spatial (Acevedo et al., 2007; Vorhees et al., 2009) memory impairments. Issues with more executive tasks have also been noted, including reversal learning (Izquierdo et al., 2010) and working memory (Mizoguchi et al., 2011). These memory impairments have also been observed in repeated-exposure ("chronic") paradigms; rodents exposed to chronic METH have displayed impairments in both object (Ito et al., 2007; Arai et al., 2009; Noda et al., 2010) and working (Nagai et al., 2007; Lee et al., 2011) memory. These impairments persist for an extended period (North et al., 2013; Braren et al., 2014), strongly suggesting that these deficits are the result of METH toxicity rather than the effects of early withdrawal from the drug.

An interesting issue with these models of METH toxicity is evidence that prior exposure to METH provides a protective effect against some of the toxicity observed in binge and chronic models (Belcher et al., 2008), which suggests tolerance to METH neurotoxicity in animal and human METH abuse, which typically features escalating usage (Simon et al., 2002). However, animals given prolonged access to METH over an extended amount of time in a self-administration paradigm, resulting in a stepwise increase in use, still show behavioral impairments consistent with human METH toxicity literature. Rodents that self-administer METH display impaired memory function (Recinto et al., 2012; Le Cozannet et al., 2013), especially object-recognition performance (Rogers et al., 2008; Reichel et al., 2011, 2012; Reichel and See, 2012; Scofield et al., 2015). Impaired object recognition in rodents primarily implicates the perirhinal cortex, but may also involve impaired hippocampal function (Olarte-Sánchez et al., 2015). Interestingly, these effects persist even in the face of an escalating dose regimen (Rogers et al., 2008; Reichel et al., 2011) mimicking the pre-exposure, which provided protective effects in the study by Belcher et al. (2008). This lends increased validity to the self-administration model and further suggests that the cognitive symptoms observed in human subjects may indeed be the result of METH neurotoxicity, rather than early withdrawal from the drug.

Self-administration models have also demonstrated impairments to spatial memory tasks, including object location (Le Cozannet et al., 2013) and Y-maze tasks (Recinto et al., 2012), more directly implicating the impairments to the hippocampus. Similar to human METH toxicity, self-administration in rodents also results in impaired attentional set shifting, a PFC-mediated executive/attentional task analogous to aspects of the human Wisconsin Card Sorting Task (Parsegian et al., 2011). In addition, rats trained to self-administer METH display impaired reversal learning in a visual attention-set 
task (Cox et al., 2016), a measure of cognitive flexibility, further implicating dysregulation of the PFC and larger frontal circuits. Although there is some evidence that METH self-administration results in prolonged impulsivity, these results are transient and should more appropriately be viewed as the result of METH withdrawal (Dalley et al., 2007). Similarly, as seen with humans (discussed later) METH selfadministration produces a depressive-like and anxiety-like phenotype in rats during early postexposure periods (Jang et al., 2013), which is consistent with METH withdrawal. Taken together, there is significant evidence that METH selfadministration results in impairments to multiple cognitive systems, including memory (both spatial and object) and executive function (including attention, planning, and flexibility). It is worth noting that the impairments in inhibitory control have also been observed in nonhuman primate models of METH abuse (Groman et al., 2013; Kangas and Bergman, 2016).

Molecular Markers of METH Neurotoxicity in Human METH Users. METH-mediated neurotoxic effects and their manifestation in METH users are similar to those observed in experimental animals; however, actual degeneration of DAergic and 5HTergic nerve terminals, or cell bodies, is questionable (Kish et al., 2017). Nevertheless, most human METH users suffer from persistent DA deficits as well as brain structural and metabolic abnormalities in the same brain areas as those affected by METH in experimental animals, suggesting dysregulation of these areas. Studies in autopsied human brains determined that three DAergic markers (DA, DAT, and TH, but not 3,4-dihydroxyphenylalanine decarboxylase and VMAT2) are decreased in the caudate, putamen, and nucleus accumbens in METH users compared with matched controls; DA deficit was more pronounced in the cognition-mediating caudate than in the motor activity-mediating putamen (Wilson et al., 1996; Moszczynska et al., 2004; Kitamura et al., 2007). In vivo imaging techniques [positron emission tomography (PET) and magnetic resonance imaging] revealed reduced density of DAT (McCann et al., 1998; Volkow et al., 2001c,d, 2015; Sekine et al., 2003), dopamine $\mathrm{D}_{2}$ receptor (Volkow et al., 2001a), VMAT2 (Johanson et al., 2006; Kitamura et al., 2007) [see Boileau et al. (2008, 2016)], SERT (Sekine et al., 2006; Kish et al., 2009), and GLU+glutamine (Ernst and Chang, 2008; O'Neill et al., 2014) in abstinent (weeks to months) human abusers of METH. The DAT was decreased in the orbitofrontal cortex, dorsolateral prefrontal cortex, dorsal striatum, nucleus accumbens, and amygdala, whereas the SERT was decreased in the orbitofrontal and occipital cortices, midbrain, thalamus, dorsal striatum, and cerebellum. Using proton magnetic resonance spectroscopy, several neuronal metabolites or their ratios were found altered (increased or decreased) in basal ganglia, anterior cingulate, and frontal cortex white matter of METH users (Ernst et al., 2000; Nordahl et al., 2002; Sekine et al., 2002; Chang et al., 2005b; Nordahl et al., 2005). Measurement of glucose metabolism in METH users by PET has shown increased global metabolism but lower relative levels of striatal and thalamic metabolism (Volkow et al., 2001b; Wang et al., 2004; Chang et al., 2007). Other CNS abnormalities detected in brains of abstinent METH users were apoptosis and microglial activation as measured by PET (Sekine et al., 2008). Microglial activation was detected in the midbrain, striatum, thalamus, orbitofrontal cortex, and insular cortex and correlated inversely with the duration of METH abstinence in the midbrain, striatum, and thalamus. On the other hand, METH users who died of drug overdose did not display microglial activation or apoptosis (Kitamura et al., 2010). Postmortem tissue studies also did not detect significant activation of astrocytes in METH users (Kitamura et al., 2010; Tong et al., 2014). However, oxidative stress and decreased phospholipid metabolism were detected in autopsied striatum of chronic METH users (Ross et al., 2002; Mirecki et al., 2004; Fitzmaurice et al., 2006).

Several structural abnormalities (gray-matter volume, fiber structure/connectivity) were detected in a variety of affected areas comprehensively reviewed by several groups (Berman et al., 2008; Tobias et al., 2010; Dean et al., 2015; London et al., 2015). Specifically, gray matter deficits were present in the cingulate, limbic, and paralimbic cortex, and hippocampus, whereas white matter was hypertrophic in the temporal and occipital cortex. In abstinent METH users, gray matter was smaller in the insular and frontal cortex, whereas in the dorsal striatum, nucleus accumbens, and globus pallidus, it was enlarged. White-matter and gray-matter abnormalities were detected in the PFC and hippocampal formation. As in rodents, the frontal cortex was affected by METH exposure, as smaller medial PFC volumes have been detected in METH and amphetamine users, which correlated with errors in the Wisconsin Card Sorting test (Kim et al., 2006; Daumann et al., 2011). Reductions in gray-matter volume in the cingulate cortex along with corresponding impairments to glucose metabolism negatively correlated with task error rates in METH users (London et al., 2005). The substantia nigra pars compacta also had abnormal morphology in METH users (Todd et al., 2013). These neuronal alterations-specifically, alterations to mesolimbic, prefrontal, hippocampal, and nigrostriatal structures-have been shown to correlate with behavioral neurologic consequences of METH neurotoxicity (Table 1).

Behavioral Markers of METH Neurotoxicity in Human METH Users. There is evidence that METH abusers display altered reward preference (Monterosso et al., 2007; Hoffman et al., 2008; Schwartz et al., 2010), indicated by an increased preference for smaller immediate rewards over greater delayed rewards. This task constitutes a type of impulsivity thought to both precipitate and result from drug use (de Wit, 2009). This preference for immediate reward is compounded by evidence suggesting an increase in risky decision making (Kohno et al., 2014), possibly the result of a circuit-based bias toward reward, as well as increased drug craving/anxiety (Yuan et al., 2017). This craving is likely related to decreased striatal DA, which in turn has been shown to precipitate METH relapse in humans (Wang et al., 2012). Taken as a whole, there is evidence that METH toxicity results in lasting functional alterations to human decision making, impulsivity, and reward circuitry.

As previously mentioned, there is extensive evidence that human METH users display impairments in executive functioning (particularly as assessed by the Wisconsin Card Sorting Task; Simon et al., 2002, 2010; Kim et al., 2005, 2009; Monterosso et al., 2005; Rendell et al., 2009). Considering this impairment, it is unsurprising that several studies have found that METH abusers showcase impairments in top-down inhibitory tasks (e.g., the Stroop task), further indicative of impaired executive control (Simon et al., 2000; Fillmore and Rush, 2002; Salo et al., 2002, 2009a,b,c; Weafer et al., 2014). These impairments strongly implicate 
structural disruption of the PFC and greater executive circuits (Tabibnia et al., 2011), indicating that these impairments are likely due to METH toxicity rather than pharmacological withdrawal. This is consistent with animal literature data suggesting that METH toxicity results in functional impairments in the PFC (Kuczenski et al., 2007). In addition, these individuals show reductions in overall task-processing speed (Simon et al., 2000; Kalechstein et al., 2003), reaction time (Lawton-Craddock et al., 2003), and motor speed (Volkow et al., 2001d).

METH abusers consistently show dysfunction in learning (McKetin and Mattick, 1998; Kalechstein et al., 2003; Henry et al., 2009) and memory tasks (Boileau et al., 2008; McKetin and Mattick, 1998; Rendell et al., 2009). This is not surprising, as METH abusers have shown reductions in hippocampal volume (Thompson et al., 2004) and alterations to functional connectivity between the midbrain and hippocampus (Kohno et al., 2014). Studies have also noted impairments to working memory (Chang et al., 2002; Gonzalez et al., 2007; Rendell et al., 2009). This is interesting, as recent evidence has suggested that cognitive training using the N-back task may be an effective adjunct for treating the symptoms of METH toxicity (Brooks et al., 2016). Unlike spatial or object-memory tasks, working memory is a global process, involving multiple circuits [for review, D'Esposito and Postle (2015)]. However, the dorsolateral PFC is particularly important in workingmemory function (Rogasch et al., 2015), and evidence suggests that METH abusers show decreased PFC activity compared with healthy controls (Salo et al., 2013).

As previously indicated, METH users also display affective symptoms, including depression (London et al., 2004), psychotic symptoms (Sekine et al., 2002, 2003), impulsivity (Andres et al., 2016), or aggressive behavior (Sekine et al., 2006). Sensitization to METH psychosis could be functionally related to neurotoxicity because psychiatric symptoms correlated inversely with DAT density in the striatum and PFC (Sekine et al., 2003). With extended abstinence from METH, METH neurotoxicity-associated brain abnormalities and neurologic problems may partially recover (Volkow et al., 2001d; Chang et al., 2007). Some papers have suggested that this is particularly true for the cognitive aspects of METH toxicity (Iudicello et al., 2010). However, several other papers have shown persistent deficits in cognitive skills with little improvement over time (Volkow et al., 2001d; Johanson et al., 2006). This discrepancy is likely related to the individual factors that underlie METH use (use pattern, dosage, genetics, age, demographics, education, polydrug use). As such, cognitive recovery from METH toxicity is an open and ongoing research topic. Some manifestations of METH neurotoxicity and related molecular mechanisms are presented in Table 1. However, the relationship between METH toxicity and cognitive impairments is not necessarily clear: prior work has suggested that METH-use parameters predict motor impairment but not cognitive impairment, suggesting that personal vulnerabilities are involved in the cognitive symptoms of METH toxicity (Cherner et al., 2010). This is consistent with the aforementioned discrepancy in recovery following METH toxicity.

As previously discussed, METH toxicity results in a host of effects at the molecular level, including a decline in DAergic markers similar to the pathology of PD. These changes, although not causative for $\mathrm{PD}$ per se, do suggest similarities between METH toxicity and PD pathogenesis (Moszczynska et al., 2004). For example, humans with a history of stimulant use have abnormal morphology of the Substantia Nigra that is itself consistent with increased risk for PD (Todd et al., 2013, 2016). In light of this, it appears that there are several phenotypic responses to METH neurotoxicity, depending in part of the frequency and magnitude of use, with some individuals seeing recovery, others being stabilized at their current impairment, and still others experiencing further damage/degeneration.

There are marked similarities between human and animal studies of METH toxicity. These studies report similar behavioral effects, including affective dysregulation (London et al., 2004; McGregor et al., 2005; Jang et al., 2013; Silva et al., 2014), memory impairment (Recinto et al., 2012; Braren et al., 2014; Brooks et al., 2016), and disruption of executive functioning (Izquierdo et al., 2010; Kohno et al., 2014). It appears that the mechanisms for these impairments are relatively well conserved between species as well-humans and animals showcase reductions in DAergic and 5HTergic signaling (Wilson et al., 1996; Friedman et al., 1998; Graham et al., 2008; Kish et al., 2009; Hensleigh and Pritchard, 2015), and do so in a variety of brain regions, including the striatum, frontal cortex, and hippocampus. Both species seem to show conflicting evidence for spontaneous recovery of lost function (Johanson et al., 2006). There are, however, functional differences between the two species. First, as previously noted, although mice remain a popular tool for assaying METH toxicity, mice see widespread cell loss not seen in humans or rats (Deng et al., 2001), which limits the direct translational value of this model. Second, although there have been advances in the field in the last 10 years, many studies of animal toxicity still rely on single-day binge-exposure models, which (as discussed earlier) can have different outcomes than longer chronic models that feature a gradual buildup in dosing to better mimic human abuse (Graham et al., 2008). Despite these shortcomings, animal research into METH toxicity has suggested several promising targets for remediating cognitive impairments observed in METH toxicity.

Molecular markers (e.g., DAT, GLU) may return to normal or close to normal levels during protracted abstinence but may not be paralleled by normalization of neurologic problems (Volkow et al., 2001c, 2015; O'Neill et al., 2014). Several crosssectional and longitudinal studies have indicated that cognitive impairments partially recover with prolonged abstinence (Volkow et al., 2001c; Wang et al., 2004; Jaffe et al., 2005; Kim et al., 2006; Salo et al., 2009) or recover in some, but not all, individuals (Iudicello et al., 2010), with a potential exception of episodic memory and cognitive inhibition (Johanson et al., 2006). For example, prefrontal gray-matter volume was more decreased in early than late abstinence from METH, but was still significantly lower than in the control subjects (Kim et al., 2006). Lower metabolism in the striatum (most accentuated in the caudate and nucleus accumbens) was detected in METH users withdrawn from the drug at least for a year (Wang et al., 2004). These changes could be associated with the effect of METH on episodic memory and executive functions. Among other indices of METH neurotoxicity, putamen and globus pallidus enlargement lasted for at least 2 years (Chang et al., 2005a). As smaller putamen volume was associated with poorer performance on verbal fluency and dexterity tests, enlarged volume was hypothesized to represent a compensatory 
TABLE 1

Manifestations of METH neurotoxicity in human subjects and experimental animals, brain areas mediating the manifestations, and underlying molecular mechanisms

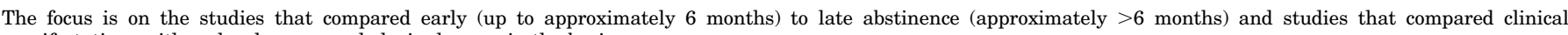
manifestations with molecular or morphologic changes in the brain.

\begin{tabular}{|c|c|c|c|c|c|}
\hline Manifestation & Dose & $\begin{array}{l}\text { Effect and Molecular } \\
\text { Mechanism (Current Use/ } \\
\text { Early Abstinence) }\end{array}$ & $\begin{array}{c}\text { Effect and Molecular } \\
\text { Mechanism (Late Abstinence) }\end{array}$ & Human Studies & Animal Studies \\
\hline Anxiety, dysphoria & $>30 \mathrm{mg}$ & $\begin{array}{l}\Delta \text { Adrenergic alpha1 } \\
\text { receptor stimulation } \\
\text { (PFC) } \\
\text { \5HT receptor and DA } \\
\text { receptor stimulation } \\
\text { (multiple areas), altered } \\
\text { glucose metabolism } \\
\text { (limbic and paralimbic } \\
\text { areas) }\end{array}$ & $\begin{array}{l}\boldsymbol{\nabla} \text { DA, } 5-\mathrm{HT} \text { and } \mathrm{NE} \\
\text { neurotransmission }\end{array}$ & $\begin{array}{l}\text { Martin et al., 1971; } \\
\text { Tong et al., 2003; } \\
\\
\text { London et al., 2004; } \\
\text { Newton et al., 2005 }\end{array}$ & $\begin{array}{l}\text { Filip et al., 2005; Berridge } \\
\text { et al., 2006; Kitanaka } \\
\text { et al., 2008; Jang et al., } \\
2013\end{array}$ \\
\hline $\begin{array}{l}\text { Elevated body } \\
\text { temperature }\end{array}$ & $>30 \mathrm{mg}$ & $\begin{array}{l}\mathbf{\Delta D A}, \text { and } 5-\mathrm{HT} \text { release } \\
\text { (hypothalamus) }\end{array}$ & & Martin et al., 1971 & $\begin{array}{l}\text { Bowyer et al., 1992, 1994; } \\
\text { Shioda et al., } 2010\end{array}$ \\
\hline $\begin{array}{l}\text { Mind racing/ } \\
\text { Talkativeness }\end{array}$ & $>50 \mathrm{mg}$ & $\begin{array}{l}\text { Anterior cingulate } \\
\text { cortex and ventral } \\
\text { striatum activity }\end{array}$ & & $\begin{array}{l}\text { Bell, 1973; Vollm et al., } \\
\quad 2004\end{array}$ & \\
\hline Paranoia/psychosis & $>55 \mathrm{mg}$ & 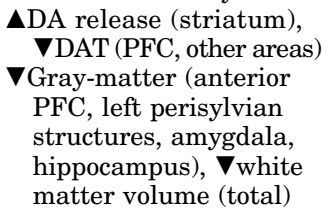 & & $\begin{array}{l}\text { Bell, 1973; Drevets et al., } \\
\text { 2001; Sekine et al., } \\
\text { 2003; Ujike et al., 2009; } \\
\text { Orikabe et al., 2011; } \\
\text { Aoki et al., 2013; Mash, } \\
2016\end{array}$ & \\
\hline $\begin{array}{l}\text { Hallucinations } \\
\text { (auditory, } \\
\text { visual) }\end{array}$ & $>55 \mathrm{mg}$ & $\begin{array}{l}\text { Auditory/Visual: } \\
\Delta \text { thalamic and ventral } \\
\text { striatum activity, } \\
\text { paralimbic system } \\
\text { and visual cortex } \\
\text { activity }\end{array}$ & & $\begin{array}{l}\text { Bell, 1973; Silbersweig } \\
\text { et al., } 1995\end{array}$ & \\
\hline $\begin{array}{l}\text { Stereotypy } \\
\text { (punding) }\end{array}$ & High & $\begin{array}{l}\mathrm{D}_{1} / \mathrm{D}_{2} \text { receptor imbalance } \\
\quad \text { (dorsal striatum) }\end{array}$ & & (Rylander, 1972) & (Ujike et al., 1989) \\
\hline $\begin{array}{l}\text { Choreoathetosis, } \\
\text { Dyskinesia }\end{array}$ & High & $\begin{array}{l}\Delta \mathrm{D}_{2} \text { receptor activity } \\
\text { (dorsal striatum) }\end{array}$ & & $\begin{array}{l}\text { (Sperling and Horowitz, } \\
\text { 1994) }\end{array}$ & (Ujike et al., 1989) \\
\hline Working Memory & $>0.25 \mathrm{~g} / \mathrm{day}$ & $\nabla$ Working memory & 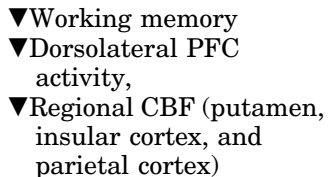 & $\begin{array}{l}\text { (Ornstein et al., 2000; } \\
\text { Chang et al., 2002; } \\
\text { Paulus et al., 2002; } \\
\text { Scott et al., 2007; } \\
\text { Rendell et al., 2009) }\end{array}$ & (Mizoguchi et al., 2011) \\
\hline Executive function & $>0.5$ g/day & 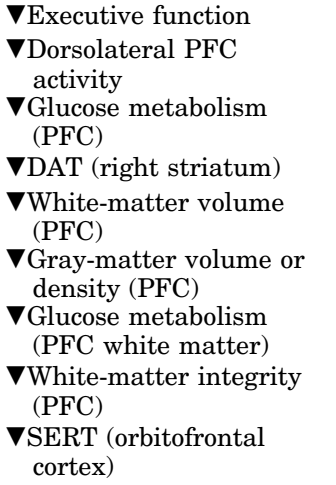 & 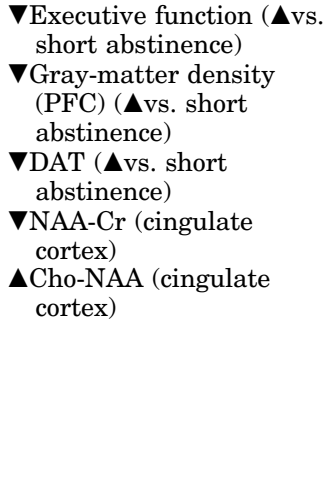 & $\begin{array}{l}\text { Paulus et al., 2002; Sim } \\
\text { et al., 2002; Kim et al., } \\
\text { 2005, 2006; London } \\
\text { et al., 2005; Chou et al., } \\
\text { 2007; Chung et al., } \\
\text { 2007; Salo et al., 2007; } \\
\text { Scott et al., 2007; } \\
\text { Berman et al., 2008; } \\
\text { Kish et al., 2009; Salo } \\
\text { et al., 2009a,b,c; Nestor } \\
\text { et al., } 2011\end{array}$ & $\begin{array}{l}\text { Izquierdo et al., 2010; } \\
\quad \text { Parsegian et al., } 2011\end{array}$ \\
\hline
\end{tabular}


TABLE 1-Continued

\begin{tabular}{|c|c|c|c|c|c|}
\hline Manifestation & Dose & $\begin{array}{l}\text { Effect and Molecular } \\
\text { Mechanism (Current Use/ } \\
\text { Early Abstinence) }\end{array}$ & $\begin{array}{c}\text { Effect and Molecular } \\
\text { Mechanism (Late Abstinence) }\end{array}$ & Human Studies & Animal Studies \\
\hline & & $\begin{array}{l}\boldsymbol{\nabla} \text { Cingulate and parietal } \\
\text { cortex glucose metabolism }\end{array}$ & & & \\
\hline Motor skills & $>0.25 \mathrm{~g} / \mathrm{day}$ & 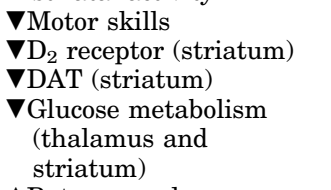 & $\begin{array}{l}\boldsymbol{\nabla} \text { Motor skills ( } \boldsymbol{\Lambda} \text { vs. short } \\
\text { abstinence) } \\
\mathbf{\Delta} \text { Thalamic glucose } \\
\text { metabolism }\end{array}$ & $\begin{array}{l}\text { Volkow et al., 2001a,d; } \\
\text { Wang et al., 2004; } \\
\text { Chang et al., 2005; } \\
\text { Cherner et al., 2010 }\end{array}$ & Wallace et al., 1999 \\
\hline $\begin{array}{l}\text { Information- } \\
\text { processing speed }\end{array}$ & $>0.5 \mathrm{~g} / \mathrm{day}$ & $\boldsymbol{\nabla}$ Processing speed & $\boldsymbol{\nabla}$ Processing speed & Scott et al., 2007 & Dalley et al., 2007 \\
\hline Visuospatial skills & $>0.5 \mathrm{~g} /$ day & 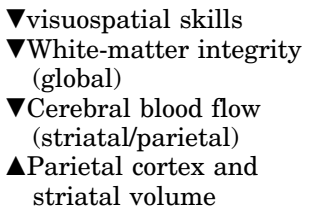 & $\begin{array}{l}\text { VVisuospatial ability } \\
\text { VCerebral blood flow } \\
\text { (striatal/parietal) }\end{array}$ & $\begin{array}{l}\text { Chang et al., 2002; } \\
\text { Kalechstein et al., 2003; } \\
\text { Jernigan et al., 2005; } \\
\text { Scott et al., 2007; } \\
\text { Kalechstein et al., } 2014\end{array}$ & \\
\hline
\end{tabular}

Abbreviations: CBF, cerebral blood flow; Cho-NAA, choline $N$-acetyl aspartate; DA, dopamine; DAT, dopamine receptor; 5 -HT, serotonin; NAA-Cr, $N$-acetyl aspartate

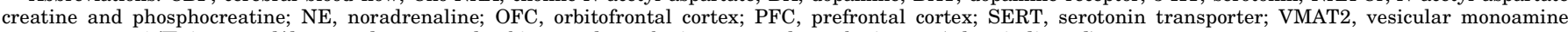
transporter $2 ; \boldsymbol{\Delta} / \boldsymbol{\nabla}$, increased/decreased vs. control subjects or long abstinence vs. short abstinence (when indicated)

response to the METH exposure driven by inflammation (Chang et al., 2005a). In support, microglial activation was long-lasting ( $\sim 2$ years on average) in several brain areas in abstinent METH users, including the striatum (Sekine et al., 2008). Increased gray-matter volume might also result from de novo axonal sprouting (Arkadir et al., 2014) or neuronal cell swelling (Rungta et al., 2015).

\section{Implications of METH Neurotoxicity for Treatment}

Although there is some evidence for spontaneous recovery of cognitive functioning following METH neurotoxicity, most evidence indicates that cognitive impairments resulting from METH toxicity, albeit mild and variable between individuals, are long lasting, if not permanent. These impairments interfere with everyday functioning (e.g., financial functioning, communication, transportation), health, and well-being, including taking medications and, importantly, adherence to antiaddiction programs (Henry et al., 2010). Moreover, METH-dependent participants with mild or greater cognitive deficits are more likely to be unemployed than cognitively unimpaired individuals (Weber et al., 2012). Some compensatory mechanisms might not be beneficial for brain function [e.g., axonal sprouting (Arkadir et al., 2014)]. Importantly, strength of craving for METH can be reduced by cognitive strategies (Lopez et al., 2015); therefore, improvement of cognitive abilities of abstinent METH users is important.
Current Treatments of Cognitive Impairments. Although there are treatments for the individual symptoms of METH neurotoxicity, there are no current interventions for the underlying pathology. However, there are several promising lines of inquiry. Some potential interventions for cognitive impairment have focused on physical interventions. For example, there is evidence that electroconvulsive shock restores object-related memory in mice in a chronic METH paradigm (Chao et al., 2012). A separate group has shown that cognitive training may remediate some of the executive impairments in human METH users (Brooks et al., 2016). Most interventions, however, are pharmacological, and focus on manipulating the DAergic and 5HTergic systems. Silibinin, a flavonoid with 5HTergic- and DAergic-releasing properties, has been shown to increase cognitive performance on memory tasks in METH-treated mice (Lu et al., 2010), possibly through inhibition of monoamine oxydase. Likewise, ZSET1446 (spiro[imidazo[1,2-a]pyridine-3,2-indan]-2(3H)-one), which increases extracellular acetylcholine, has been shown to reverse memory impairments induced by METH toxicity (Ito et al., 2007 ), most likely through indirect activation of $D_{1}$ dopamine receptors. The stimulant modafinil has been the subject of several clinical trials as a possible intervention for METH dependence and as a booster of cognitive performance in METH-dependent individuals. However, it may also be beneficial in the treatment of METH toxicity, as modafinil has been shown to improve working memory performance (N-back task) in abstinent METH-dependent individuals who showed baseline impairments in working memory indicative of 
toxicity (Kalechstein et al., 2010). This report is corroborated by animal studies showing that modafinil reverses objectmemory impairments induced by subchronic METH treatment in mice (González et al., 2014), possibly by restoring extracellular signal-regulated kinase signaling in the PFC. These results appear to be independent of GLUergic signaling (Reichel et al., 2014), and may extend to protecting against other neurologic markers of METH toxicity (Raineri et al., 2012). Although these methods show promise, more and larger clinical trials are required to demonstrate their efficacy in reversing or protecting against METH neurotoxicity.

Potential New Approaches for Treatment of METHDependent Individuals. Neurobehavioral abnormalities in METH users vary between individuals according to use pattern, dosage, age, demographics, education, polydrug use, and genetic factors. Moreover, they may be linked to pre-existing abnormalities (68 in Cadet). Many molecular mechanisms underlying cognitive impairments in METH-dependent individuals are different in early than late abstinence. Consequently, treatment of METH users should be developed on an individual basis and involve neuropsychological and neuroimaging assessments as well as careful examination of health histories and history of drug use. This approach will allow for the development of specific approaches that would most benefit each individual. Therapeutic approaches may be the most effective if combining cognitive or pharmacological treatments. For example, currently used treatments with cognitive-behavior therapy and contingency management could be combined with administration of DA-, 5HT-, and acetylcholine-releasing pharmaceuticals (see Current Treatments of Cognitive Impairments for details). METH neurotoxicity is not progressive in nature and takes place mostly during administration of the drug. In experimental animals, only a few compounds were able to attenuate METH neurotoxicity when administered after METH binge -namely, DA uptake inhibitors, nicotinic receptor ligand lobeline (Eyerman and Yamamoto, 2005), and trophic factors (e.g., GDNF) (Cass et al., 2000); these are potential candidates for treatment of cognitive impairments in METH-dependent patients. Other options include stimulation of endogenous defense/repair mechanism [e.g., DNA repair (Brooks, 2002) as well as protein and mitochondria repair via degradation pathways (Castino et al., 2008; Narendra et al., 2008; Liu et al., 2013)], administration of anti-inflammatory medications (Asanuma et al., 2003), reversal of epigenetic changes induced by METH [epigenetic changes are triggered by neurotoxic METH doses (Cadet et al., 2015; Moszczynska et al., 2015)], and/or targeted delivery of $\mathrm{Cl}^{-}$ and $\mathrm{Na}^{+}$channel and exchanger inhibitors [neuronal swelling, which may contribute to enlarged brain areas, depends on $\mathrm{Na}^{+}$ and $\mathrm{Cl}^{-}$influx (Rungta et al., 2015)]; however, benefits of these approaches remain to be tested.

\section{Summary}

METH dependence is a chronic and debilitating illness with no current pharmacological treatment. Chronic METH users often c-abuse other drugs. Therefore, it is imperative to understand molecular mechanisms and manifestations of METH neurotoxicity as well as drug-drug interaction between METH and other drugs that may have fatal consequences. The bulk of clinical efforts are focused on METH dependence; however, this review demonstrates that the toxic effects of METH are serious, long-lasting, and presently have no empirically validated remediation. Few clinical trials have investigated or intervened in the cognitive-behavioral consequences of METH toxicity directly. This is interesting, as there are a wealth of preclinical and humansubject data suggesting both physiologic and neurochemical targets for intervention. This review provides evidence for METH neurotoxicity affecting functioning of multiple brain areas, primarily the striatum, PFC, and hippocampus. Additionally, we argue that, although spontaneous remission of cognitive impairments may be possible, there is far more evidence for METH neurotoxicity resulting in either long-lasting cognitive deficits or even further decline into PD pathology. There is a present need for interventions targeted specifically against dysfunction of DA and $5 \mathrm{HT}$ systems and the broad-spectrum cognitive impairments they underpin.

\section{Authorship Contributions}

Wrote or contributed to the writing of the manuscript: Moszczynska, Callan.

\section{References}

Acevedo SF, de Esch IJ, and Raber J (2007) Sex- and histamine-dependent long-term cognitive effects of methamphetamine exposure. Neuropsychopharmacology 32 : $665-672$.

Ali SF, Newport GD, Holson RR, Slikker, Jr W, and Bowyer JF (1994) Low environmental temperatures or pharmacologic agents that produce hypothermia decrease methamphetamine neurotoxicity in mice. Brain Res 658:33-38.

Anderson KL and Itzhak Y (2006) Methamphetamine-induced selective dopaminergic neurotoxicity is accompanied by an increase in striatal nitrate in the mouse. Ann N Y Acad Sci 1074:225-233.

Andres T, Ernst T, Oishi K, Greenstein D, Nakama H, and Chang L (2016) Brain Microstructure and Impulsivity Differ between Current and Past Methamphetamine Users. J Neuroimmune Pharmacol 11:531-541.

Aoki Y, Orikabe L, Takayanagi Y, Yahata N, Mozue Y, Sudo Y, Ishii T, Itokawa M, Suzuki M, Kurachi M, et al. (2013) Volume reductions in frontopolar and left perisylvian cortices in methamphetamine induced psychosis. Schizophr Res 147:355-361.

Arai S, Takuma K, Mizoguchi H, Ibi D, Nagai T, Kamei H, Kim HC, and Yamada K (2009) GABAB receptor agonist baclofen improves methamphetamine-induced cognitive deficit in mice. Eur $J$ Pharmacol 602:101-104.

Ares-Santos S, Granado N, Espadas I, Martinez-Murillo R, and Moratalla R (2014) Methamphetamine causes degeneration of dopamine cell bodies and terminals of the nigrostriatal pathway evidenced by silver staining. Neuropsychopharmacology 39:1066-1080

Arkadir D, Bergman H, and Fahn S (2014) Redundant dopaminergic activity may enable compensatory axonal sprouting in Parkinson disease. Neurology 82:1093-1098.

Asanuma M, Tsuji T, Miyazaki I, Miyoshi K, and Ogawa N (2003) Methamphetamineinduced neurotoxicity in mouse brain is attenuated by ketoprofen, a non-steroidal anti-inflammatory drug. Neurosci Lett 352:13-16.

Balster RL and Schuster CR (1973) A comparison of d-amphetamine, l-amphetamine, and methamphetamine self-administration in rhesus monkeys. Pharmacol Biochem Behav 1:67-71.

Beauvais G, Atwell K, Jayanthi S, Ladenheim B, and Cadet JL (2011) Involvement of dopamine receptors in binge methamphetamine-induced activation of endoplasmic reticulum and mitochondrial stress pathways. PLoS One 6:e28946.

Belcher AM, Feinstein EM, O'Dell SJ, and Marshall JF (2008) Methamphetamine influences on recognition memory: comparison of escalating and single-day dosing regimens. Neuropsychopharmacology 33:1453-1463.

Belcher AM, O'Dell SJ, and Marshall JF (2005) Impaired object recognition memory following methamphetamine, but not p-chloroamphetamine- or d-amphetamineinduced neurotoxicity. Neuropsychopharmacology 30:2026-2034.

Bell DS (1973) The experimental reproduction of amphetamine psychosis. Arch Gen Psychiatry 29:35-40.

Berman S, O'Neill J, Fears S, Bartzokis G, and London ED (2008) Abuse of amphetamines and structural abnormalities in the brain. Ann N Y Acad Sci 1141:195-220.

Berridge CW (2006) Neural substrates of psychostimulant-induced arousal. Neuropsychopharmacology 31:2332-2340.

Boileau I, McCluskey T, Tong J, Furukawa Y, Houle S, and Kish SJ (2016) Rapid Recovery of Vesicular Dopamine Levels in Methamphetamine Users in Early Abstinence. Neuropsychopharmacology 41:1179-1187.

Boileau I, Rusjan P, Houle S, Wilkins D, Tong J, Selby P, Guttman M, Saint-Cyr JA, Wilson AA, and Kish SJ (2008) Increased vesicular monoamine transporter binding during early abstinence in human methamphetamine users: Is VMAT2 a stable dopamine neuron biomarker? J Neurosci 28:9850-9856.

Boireau A, Bordier F, Dubédat P, and Doble A (1995) Methamphetamine and dopamine neurotoxicity: differential effects of agents interfering with glutamatergic transmission. Neurosci Lett 195:9-12.

Bowyer JF and Schmued LC (2006) Fluoro-Ruby labeling prior to an amphetamine neurotoxic insult shows a definitive massive loss of dopaminergic terminals and axons in the caudate-putamen. Brain Res 1075:236-239.

Bowyer JF, Davies DL, Schmued L, Broening HW, Newport GD, Slikker W, and Holson RR (1994). Further studies of the role of hyperthermia in methamphetamine neurotoxicity. Journal of Pharmacology and Experimental Therapeutics, 268(3): $1571-1580$ 
Bowyer JF, Tank AW, Newport GD, Slikker, Jr W, Ali SF, and Holson RR (1992) The influence of environmental temperature on the transient effects of methamphetamine on dopamine levels and dopamine release in rat striatum. J Pharmacol Exp Ther 260:817-824.

Braren SH, Drapala D, Tulloch IK, and Serrano PA (2014) Methamphetamineinduced short-term increase and long-term decrease in spatial working memory affects protein Kinase $\mathrm{M}$ zeta $(\mathrm{PKM} \zeta)$, dopamine, and glutamate receptors. Front Behav Neurosci 8:438.

Broening HW, Pu C, and Vorhees CV (1997) Methamphetamine selectively damages dopaminergic innervation to the nucleus accumbens core while sparing the shell. Synapse 27:153-160.

Brooks PJ (2002) DNA repair in neural cells: basic science and clinical implications. Mutat Res 509:93-108.

Brooks SJ, Burch KH, Maiorana SA, Cocolas E, Schioth HB, Nilsson EK, Kamaloodien $\mathrm{K}$, and Stein DJ (2016) Psychological intervention with working memory training increases basal ganglia volume: A VBM study of inpatient treatment for methamphetamine use. Neuroimage Clin 12:478-491.

Brotchie J and Fitzer-Attas C (2009) Mechanisms compensating for dopamine loss in early Parkinson disease. Neurology 72(7, Suppl)S32-S38.

Brown JM, Hanson GR, and Fleckenstein AE (2000) Methamphetamine rapidly decreases vesicular dopamine uptake. J Neurochem 74:2221-2223.

Cadet JL, Brannock C, Jayanthi S, and Krasnova IN (2015) Transcriptional and epigenetic substrates of methamphetamine addiction and withdrawal: evidence from a long-access self-administration model in the rat. Mol Neurobiol 51:696-717.

Cadet JL, Jayanthi S, and Deng X (2003) Speed kills: cellular and molecular bases of methamphetamine-induced nerve terminal degeneration and neuronal apoptosis. FASEB J 17:1775-1788.

Callaghan RC, Cunningham JK, Sajeev G, and Kish SJ (2010) Incidence of Parkinson's disease among hospital patients with methamphetamine-use disorders. Mov Disord 25:2333-2339.

Callaghan RC, Cunningham JK, Sykes J, and Kish SJ (2012) Increased risk of Parkinson's disease in individuals hospitalized with conditions related to the use of methamphetamine or other amphetamine-type drugs. Drug Alcohol Depend 120:35-40.

Carvalho M, Carmo H, Costa VM, Capela JP, Pontes H, Remião F, Carvalho F, and Bastos MdeL (2012) Toxicity of amphetamines: an update. Arch Toxicol 86:1167-1231.

Cass WA and Manning MW (1999) Recovery of presynaptic dopaminergic functioning in rats treated with neurotoxic doses of methamphetamine. J Neurosci 19:7653-7660.

Cass WA, Manning MW, and Bailey SL (2000) Restorative effects of GDNF on striata dopamine release in rats treated with neurotoxic doses of methamphetamine. Ann NY Acad Sci 914:127-136.

Castino R, Lazzeri G, Lenzi P, Bellio N, Follo C, Ferrucci M, Fornai F, and Isidoro C (2008) Suppression of autophagy precipitates neuronal cell death following low doses of methamphetamine. J Neurochem 106:1426-1439.

Chang L, Alicata D, Ernst T, and Volkow N (2007) Structural and metabolic brain changes in the striatum associated with methamphetamine abuse. Addiction 102 (Suppl 1):16-32.

Chang L, Cloak C, Patterson K, Grob C, Miller EN, and Ernst T (2005a) Enlarged striatum in abstinent methamphetamine abusers: a possible compensatory response. Biol Psychiatry 57:967-974.

Chang L, Ernst T, Speck O, and Grob CS (2005b) Additive effects of HIV and chronic methamphetamine use on brain metabolite abnormalities. Am J Psychiatry 162:361-369 Chang L, Ernst T, Speck O, Patel H, DeSilva M, Leonido-Yee M, and Miller EN (2002) Perfusion MRI and computerized cognitive test abnormalities in abstinent methamphetamine users. Psychiatry Res 114:65-79.

Chao YL, Chen HH, and Chen CH (2012) Effects of repeated electroconvulsive shock on methamphetamine-induced behavioral abnormalities in mice. Brain Stimulat 5 393-401.

Chen CK, Lin SK, Chen YC, Huang MC, Chen TT, Ree SC, and Wang LJ (2015) Persistence of psychotic symptoms as an indicator of cognitive impairment in methamphetamine users. Drug Alcohol Depend 148:158-164.

Cherner M, Suarez P, Casey C, Deiss R, Letendre S, Marcotte T, Vaida F, Atkinson JH, Grant I, and Heaton RK; HNRC Group (2010) Methamphetamine use parameters do not predict neuropsychological impairment in currently abstinent dependent adults. Drug Alcohol Depend 106:154-163.

Chou YH, Huang WS, Su TP, Lu RB, Wan FJ, and Fu YK (2007) Dopamine transporters and cognitive function in methamphetamine abuser after a short abstinence: A SPECT study. European Neuropsychopharmacology 17(1):46-52.

Chuang JY, Chang WT, Cherng CG, Kao GS, and Yu L (2011) Repeated co-administrations of alcohol-and methamphetamine-produced anxiogenic effect could be associated with the neurotoxicity in the dentate gyrus. J Neural Transm (Vienna) 118:1559-1569.

Cloutier RL, Hendrickson RG, Fu RR, and Blake B (2013) Methamphetamine-related psychiatric visits to an urban academic emergency department: an observational study. J Emerg Med 45:136-142.

Cody JT, Valtier S, and Nelson SL (2003) Amphetamine enantiomer excretion profile following administration of Adderall. J Anal Toxicol 27:485-492.

Comer SD, Hart CL, Ward AS, Haney M, Foltin RW, and Fischman MW (2001) Effects of repeated oral methamphetamine administration in humans. Psychopharmacology (Berl) 155:397-404.

Cook CE, Jeffcoat AR, Hill JM, Pugh DE, Patetta PK, Sadler BM, White WR, and PerezReyes M (1993) Pharmacokinetics of methamphetamine self-administered to human subjects by smoking S-(+)-methamphetamine hydrochloride. Drug Metab Dispos 21: $717-723$.

Cook CE, Jeffcoat AR, Sadler BM, Hill JM, Voyksner RD, Pugh DE, White WR, and Perez-Reyes M (1992) Pharmacokinetics of oral methamphetamine and effects of repeated daily dosing in humans. Drug Metab Dispos 20:856-862.

Courtney KE and Ray LA (2014) Methamphetamine: an update on epidemiology, pharmacology, clinical phenomenology, and treatment literature. Drug Alcohol Depend 143:11-21.

Cox BM, Cope ZA, Parsegian A, Floresco SB, Aston-Jones G, and See RE (2016) Chronic methamphetamine self-administration alters cognitive flexibility in male rats. Psychopharmacology (Berl) 233:2319-2327.
Curtin K, Fleckenstein AE, Robison RJ, Crookston MJ, Smith KR, and Hanson GR (2015) Methamphetamine/amphetamine abuse and risk of Parkinson's disease in Utah: a population-based assessment. Drug Alcohol Depend 146:30-38.

Dalley JW, Lääne K, Theobald DE, Peña Y, Bruce CC, Huszar AC, Wojcieszek M, Everitt BJ, and Robbins TW (2007) Enduring deficits in sustained visual attention during withdrawal of intravenous methylenedioxymethamphetamine selfadministration in rats: results from a comparative study with d-amphetamine and methamphetamine. Neuropsychopharmacology 32:1195-1206.

Daumann J, Koester P, Becker B, Wagner D, Imperati D, Gouzoulis-Mayfrank E, and Tittgemeyer M (2011) Medial prefrontal gray matter volume reductions in users of amphetamine-type stimulants revealed by combined tract-based spatial statistics and voxel-based morphometry. Neuroimage 54:794-801.

Dean AC, Groman SM, Morales AM, and London ED (2013) An evaluation of the evidence that methamphetamine abuse causes cognitive decline in humans. Neuropsychopharmacology 38:259-274.

Dean AC, Kohno M, Morales AM, Ghahremani DG, and London ED (2015) Denial in methamphetamine users: Associations with cognition and functional connectivity in brain. Drug Alcohol Depend 151:84-91.

Deng X, Wang Y, Chou J, and Cadet JL (2001) Methamphetamine causes widespread apoptosis in the mouse brain: evidence from using an improved TUNEL histochemical method. Brain Res Mol Brain Res 93:64-69.

D'Esposito M and Postle BR (2015) The cognitive neuroscience of working memory. Annu Rev Psychol 66:115-142.

de Wit $\mathrm{H}$ (2009) Impulsivity as a determinant and consequence of drug use: a review of underlying processes. Addict Biol 14:22-31.

Drevets WC, Gautier C, Price JC, Kupfer DJ, Kinahan PE, Grace AA, Price JL, and Mathis CA (2001) Amphetamine-induced dopamine release in human ventral striatum correlates with euphoria. Biol Psychiatry 49:81-96.

Easton N, Steward C, Marshall F, Fone K, and Marsden C (2007) Effects of amphetamine isomers, methylphenidate and atomoxetine on synaptosomal and synaptic vesicle accumulation and release of dopamine and noradrenaline in vitro in the rat brain. Neuropharmacology 52:405-414.

Egashira T and Yamanaka Y (1993) Changes in monoamine oxidase activity in mouse brain associated with d-methamphetamine dependence and withdrawal. Biochem Pharmacol 46:609-614.

Eisch AJ, Gaffney M, Weihmuller FB, O'Dell SJ, and Marshall JF (1992) Striatal subregions are differentially vulnerable to the neurotoxic effects of methamphetamine. Brain Res 598:321-326.

Eisch AJ, O'Dell SJ, and Marshall JF (1996) Striatal and cortical NMDA receptors are altered by a neurotoxic regimen of methamphetamine. Synapse 22:217-225.

Ernst T and Chang L (2008) Adaptation of brain glutamate plus glutamine during abstinence from chronic methamphetamine use. J Neuroimmune Pharmacol 3:165-172.

Ernst T, Chang L, Leonido-Yee M, and Speck O (2000) Evidence for long-term neurotoxicity associated with methamphetamine abuse: A 1H MRS study. Neurology 54:1344-1349.

Eyerman DJ and Yamamoto BK (2005) Lobeline attenuates methamphetamineinduced changes in vesicular monoamine transporter 2 immunoreactivity and monoamine depletions in the striatum. J Pharmacol Exp Ther 312:160-169.

Filip M, Frankowska M, Zaniewska M, Gołda A, and Przegaliński E (2005) The serotonergic system and its role in cocaine addiction. Pharmacol Rep 57:685-700.

Fillmore MT and Rush CR (2002) Impaired inhibitory control of behavior in chronic cocaine users. Drug Alcohol Depend 66:265-273.

Fitzmaurice PS, Tong J, Yazdanpanah M, Liu PP, Kalasinsky KS, and Kish SJ (2006) Levels of 4-hydroxynonenal and malondialdehyde are increased in brain of human chronic users of methamphetamine. J Pharmacol Exp Ther 319:703-709.

Fleckenstein AE, Metzger RR, Wilkins DG, Gibb JW, and Hanson GR (1997) Rapid and reversible effects of methamphetamine on dopamine transporters. J Pharmacol Exp Ther 282:834-838.

Friedman SD, Castañeda E, and Hodge GK (1998) Long-term monoamine depletion, differential recovery, and subtle behavioral impairment following methamphetamineinduced neurotoxicity. Pharmacol Biochem Behav 61:35-44.

Fujikawa DG, Pais ES, Aviles, Jr ER, Hsieh KC, and Bashir MT (2016) Methamphetamine-induced neuronal necrosis: the role of electrographic seizure discharges. Neurotoxicology 52:84-88.

Garwood ER, Bekele W, McCulloch CE, and Christine CW (2006) Amphetamine exposure is elevated in Parkinson's disease. Neurotoxicology 27:1003-1006.

Ghahremani DG, Tabibnia G, Monterosso J, Hellemann G, Poldrack RA, and London ED (2011) Effect of modafinil on learning and task-related brain activity in methamphetamine-dependent and healthy individuals. Neuropsychopharmacology 36(5): 950-959.

Gold MS, Kobeissy FH, Wang KK, Merlo LJ, Bruijnzeel AW, Krasnova IN, and Cadet JL (2009) Methamphetamine- and trauma-induced brain injuries: comparative cellular and molecular neurobiological substrates. Biol Psychiatry 66:118-127.

González B, Raineri M, Cadet JL, García-Rill E, Urbano FJ, and Bisagno V (2014) Modafinil improves methamphetamine-induced object recognition deficits and restores prefrontal cortex ERK signaling in mice. Neuropharmacology 87:188-197.

Gonzalez R, Bechara A, and Martin EM (2007) Executive functions among individuals with methamphetamine or alcohol as drugs of choice: preliminary observations. J Clin Exp Neuropsychol 29:155-159.

Goodman LS, Hardman JG, Limbird LE, and Gilman AG (2001) Goodman \& Gilman's The Pharmacological Basis of Therapeutics, McGraw-Hill, New York.

Goodwin JS, Larson GA, Swant J, Sen N, Javitch JA, Zahniser NR, De Felice LJ, and Khoshbouei H (2009) Amphetamine and methamphetamine differentially affect dopamine transporters in vitro and in vivo. J Biol Chem 284:2978-2989.

Gossop MR, Bradley BP, and Brewis RK (1982) Amphetamine withdrawal and sleep disturbance. Drug Alcohol Depend 10:177-183.

Graham DL, Noailles PA, and Cadet JL (2008) Differential neurochemical consequences of an escalating dose-binge regimen followed by single-day multiple-dose methamphetamine challenges. $J$ Neurochem 105:1873-1885.

Granado N, Ares-Santos S, O'Shea E, Vicario-Abejón C, Colado MI, and Moratalla R (2010) Selective vulnerability in striosomes and in the nigrostriatal dopaminergic 
pathway after methamphetamine administration : early loss of $\mathrm{TH}$ in striosomes after methamphetamine. Neurotox Res 18:48-58.

Groman SM, Morales AM, Lee B, London ED, and Jentsch JD (2013) Methamphetamineinduced increases in putamen gray matter associate with inhibitory control. Psychopharmacology (Berl) 229:527-538.

Gross NB, Duncker PC, and Marshall JF (2011) Striatal dopamine D1 and D2 receptors: widespread influences on methamphetamine-induced dopamine and serotonin neurotoxicity. Synapse 65:1144-1155.

Guilarte TR, Nihei MK, McGlothan JL, and Howard AS (2003) Methamphetamineinduced deficits of brain monoaminergic neuronal markers: distal axotomy or neuronal plasticity. Neuroscience 122:499-513.

Gulaboski R, Cordeiro MNDS, Milhazes N, Garrido J, Borges F, Jorge M, Pereira CM, Bogeski I, Morales AH, Naumoski B, et al. (2007) Evaluation of the lipophilic properties of opioids, amphetamine-like drugs, and metabolites through electrochemical studies at the interface between two immiscible solutions. Anal Biochem 361:236-243.

Gutierrez A, Jablonski SA, Amos-Kroohs RM, Barnes AC, Williams MT, and Vorhees CV (2017) Effects of Housing on Methamphetamine-Induced Neurotoxicity and Spatial Learning and Memory. ACS Chem Neurosci DOI: 10.1021/acschemneuro.6b00419 [published ahead of print].

Hall MG, Alhassoon OM, Stern MJ, Wollman SC, Kimmel CL, Perez-Figueroa A, and Radua J (2015) Gray matter abnormalities in cocaine versus methamphetaminedependent patients: a neuroimaging meta-analysis. Am J Drug Alcohol Abuse 41: 290-299.

Hart CL, Gunderson EW, Perez A, Kirkpatrick MG, Thurmond A, Comer SD, and Foltin RW (2008) Acute physiological and behavioral effects of intranasal methamphetamine in humans. Neuropsychopharmacology 33:1847-1855.

Hart CL, Marvin CB, Silver R, and Smith EE (2012) Is cognitive functioning impaired in methamphetamine users? A critical review. Neuropsychopharmacology 37:586-608.

Hart CL, Ward AS, Haney M, Foltin RW, and Fischman MW (2001) Methamphetamine self-administration by humans. Psychopharmacology (Berl) 157:75-81.

Harvey BK, Chou J, Shen H, Hoffer BJ, and Wang Y (2009) Diadenosine tetraphosphate reduces toxicity caused by high-dose methamphetamine administration. Neurotoxicology 30:436-444.

Harvey DC, Laćan G, and Melegan WP (2000a) Regional heterogeneity of dopaminergic deficits in vervet monkey striatum and substantia nigra after methamphetamine exposure. Exp Brain Res 133:349-358.

Harvey DC, Lacan G, Tanious SP, and Melega WP (2000b) Recovery from methamphetamine induced long-term nigrostriatal dopaminergic deficits without substantia nigra cell loss. Brain Res 871:259-270.

He J, Yang Y, Yu Y, Li X, and Li XM (2006) The effects of chronic administration of quetiapine on the methamphetamine-induced recognition memory impairment and dopaminergic terminal deficit in rats. Behav Brain Res 172:39-45.

Heikkila RE, Orlansky H, Mytilineou C, and Cohen G (1975) Amphetamine: evaluation of $\mathrm{d}$ - and l-isomers as releasing agents and uptake inhibitors for $3 \mathrm{H}$-dopamine and $3 \mathrm{H}$-norepinephrine in slices of rat neostriatum and cerebral cortex. J Pharmacol Exp Ther 194:47-56.

Henry BL, Minassian A, and Perry W (2010) Effect of methamphetamine dependence on everyday functional ability. Addict Behav 35:593-598.

Henry JD, Mazur M, and Rendell PG (2009) Social-cognitive difficulties in former users of methamphetamine. Br J Clin Psychol 48:323-327.

Hensleigh E and Pritchard LM (2015) Maternal separation increases methamphetamineinduced damage in the striatum in male, but not female rats. Behav Brain Res 295:3-8.

Hensley D and Cody JT (1999) Simultaneous determination of amphetamine, methamphetamine, methylenedioxyamphetamine (MDA), methylenedioxymethamphetamine (MDMA), and methylenedioxyethylamphetamine (MDEA) enantiomers by GC-MS. $J$ Anal Toxicol 23:518-523.

Herring NR, Schaefer TL, Gudelsky GA, Vorhees CV, and Williams MT (2008) Effect of +-methamphetamine on path integration learning, novel object recognition, and neurotoxicity in rats. Psychopharmacology (Berl) 199:637-650.

Hoffman WF, Schwartz DL, Huckans MS, McFarland BH, Meiri G, Stevens AA and Mitchell SH (2008) Cortical activation during delay discounting in abstinent methamphetamine dependent individuals. Psychopharmacology (Berl) 201:183-193.

Hori N, Kadota MT, Watanabe M, Ito Y, Akaike N, and Carpenter DO (2010) Neurotoxic effects of methamphetamine on rat hippocampus pyramidal neurons. Cell Mol Neurobiol 30:849-856.

Hotchkiss AJ and Gibb JW (1980) Long-term effects of multiple doses of methamphetamine on tryptophan hydroxylase and tyrosine hydroxylase activity in rat brain. J Pharmacol Exp Ther 214:257-262.

Hsieh JH, Stein DJ, and Howells FM (2014) The neurobiology of methamphetamine induced psychosis. Front Hum Neurosci 8:537.

Ito Y, Takuma K, Mizoguchi H, Nagai T, and Yamada K (2007) A novel azaindolizinone derivative ZSET1446 (spiro[imidazo[1,2-a]pyridine-3,2-indan]-2(3H)-one) improve methamphetamine-induced impairment of recognition memory in mice by activating extracellular signal-regulated kinase 1/2. J Pharmacol Exp Ther 320:819-827.

Iudicello JE, Woods SP, Vigil O, Scott JC, Cherner M, Heaton RK, Atkinson JH, and Grant I; HIV Neurobehavioral Research Center (HNRC) Group (2010) Longer term improvement in neurocognitive functioning and affective distress among methamphetamine users who achieve stable abstinence. J Clin Exp Neuropsychol 32:704-718.

Izquierdo A, Belcher AM, Scott L, Cazares VA, Chen J, O’Dell SJ, Malvaez M, Wu T, and Marshall JF (2010) Reversal-specific learning impairments after a binge regimen of methamphetamine in rats: possible involvement of striatal dopamine. Neuropsychopharmacology 35:505-514.

Jackson DM, Andén NE, and Dahlström A (1975) A functional effect of dopamine in the nucleus accumbens and in some other dopamine-rich parts of the rat brain. Psychopharmacology (Berl) 45:139-149.

Jaffe C, Bush KR, Straits-Troster K, Meredith C, Romwall L, Rosenbaum G, Cherrier M, and Saxon AJ (2005) A comparison of methamphetamine-dependent inpatients childhood attention deficit hyperactivity disorder symptomatology. J Addict Dis 24:133-152.
Jang CG, Whitfield T, Schulteis G, Koob GF, and Wee S (2013) A dysphoric-like state during early withdrawal from extended access to methamphetamine selfadministration in rats. Psychopharmacology (Berl) 225:753-763.

Jayanthi S, Deng X, Noailles PA, Ladenheim B, and Cadet JL (2004) Methamphetamine induces neuronal apoptosis via cross-talks between endoplasmic reticulum and mitochondria-dependent death cascades. FASEB $J$ 18:238-251.

Jernigan TL, Gamst AC, Archibald SL, Fennema-Notestine C, Mindt MR, Marcotte TD, Heaton RK, Ellis RJ, and Grant I (2005) Effects of methamphetamine dependence and HIV infection on cerebral morphology. Am J Psychiatry 162: $1461-1472$

Johanson CE, Frey KA, Lundahl LH, Keenan P, Lockhart N, Roll J, Galloway GP, Koeppe RA, Kilbourn MR, Robbins T, et al. (2006) Cognitive function and nigrostriatal markers in abstinent methamphetamine abusers. Psychophar macology (Berl) 185:327-338.

Johnson M, Stone DM, Hanson GR, and Gibb JW (1987) Role of the dopaminergic nigrostriatal pathway in methamphetamine-induced depression of the neostriatal serotonergic system. Eur J Pharmacol 135:231-234.

Jones ES and Rayner BL (2015) Hypertension, end-stage renal disease and mesangiocapillary glomerulonephritis in methamphetamine users. $S$ Afr Med J 105:199-201.

Jumnongprakhon P, Govitrapong P, Tocharus C, Tungkum W, and Tocharus J (2014) Protective effect of melatonin on methamphetamine-induced apoptosis in glioma cell line. Neurotox Res 25:286-294.

Kalasinsky KS, Bosy TZ, Schmunk GA, Reiber G, Anthony RM, Furukawa Y, Guttman M, and Kish SJ (2001) Regional distribution of methamphetamine in autopsied brain of chronic human methamphetamine users. Forensic Sci Int 116 163-169.

Kalechstein AD, De La Garza, 2nd R, and Newton TF (2010) Modafinil administration improves working memory in methamphetamine-dependent individuals who demonstrate baseline impairment. Am J Addict 19:340-344.

Kalechstein AD, Mahoney JJ, Verrico CD, and De La Garza R (2014) Short-term, low-dose varenicline administration enhances information processing speed in methamphetamine-dependent users. Neuropharmacology 85:493-498.

Kalechstein AD, Newton TF, and Green M (2003) Methamphetamine dependence is associated with neurocognitive impairment in the initial phases of abstinence. $J$ Neuropsychiatry Clin Neurosci 15:215-220.

Kangas BD and Bergman J (2016) Effects of self-administered methamphetamine on discrimination learning and reversal in nonhuman primates. Psychopharmacology (Berl) 233:373-380.

Keller CM, Salvatore MF, Pruett BS, Guerin GF, and Goeders NE (2011) Biphasic dopamine regulation in mesoaccumbens pathway in response to non-contingent binge and escalating methamphetamine regimens in the Wistar rat. Psychopharmacology (Berl) 215:513-526.

Kesby JP, Chang A, Markou A, and Semenova S (2017) Modeling human methamphetamine use patterns in mice: chronic and binge methamphetamine exposure, reward function and neurochemistry. Addict Biol DOI: 10.1111/adb.12502 [published ahead of print].

Killinger BA and Moszczynska A (2016) Epothilone D prevents binge methamphetamine-mediated loss of striatal dopaminergic markers. J Neurochem 136:510-525.

Kim SJ, Lyoo IK, Hwang J, Chung A, Hoon Sung Y, Kim J, Kwon DH, Chang KH, and Renshaw PF (2006) Prefrontal grey-matter changes in short-term and longterm abstinent methamphetamine abusers. Int $J$ Neuropsychopharmacol 9: $221-228$

Kim SJ, Lyoo IK, Hwang J, Sung YH, Lee HY, Lee DS, Jeong DU, and Renshaw PF (2005) Frontal glucose hypometabolism in abstinent methamphetamine users. Neuropsychopharmacology 30:1383-1391.

Kim YT, Lee SW, Kwon DH, Seo JH, Ahn BC, and Lee J (2009) Dose-dependent frontal hypometabolism on FDG-PET in methamphetamine abusers. J Psychiatr Res 43:1166-1170.

Kirkpatrick MG, Gunderson EW, Johanson CE, Levin FR, Foltin RW, and Hart CL (2012) Comparison of intranasal methamphetamine and d-amphetamine self administration by humans. Addiction 107:783-791

Kish SJ, Boileau I, Callaghan RC, and Tong J (2017) Brain dopamine neurone 'damage': methamphetamine users vs. Parkinson's disease - a critical assessment of the evidence. Eur $J$ Neurosci 45:58-66.

Kish SJ, Fitzmaurice PS, Boileau I, Schmunk GA, Ang LC, Furukawa Y, Chang LJ, Wickham DJ, Sherwin A, and Tong J (2009) Brain serotonin transporter in human methamphetamine users. Psychopharmacology (Berl) 202:649-661.

Kitanaka J, Kitanaka N, and Takemura M (2008) Neurochemical consequences of dysphoric state during amphetamine withdrawal in animal models: a review. Neurochem Res 33:204-219.

Kitamura O, Takeichi T, Wang EL, Tokunaga I, Ishigami A, and Kubo S (2010) Microglial and astrocytic changes in the striatum of methamphetamine abusers. Leg Med (Tokyo) 12:57-62.

Kitamura O, Tokunaga I, Gotohda T, and Kubo S (2007) Immunohistochemical in vestigation of dopaminergic terminal markers and caspase-3 activation in the striatum of human methamphetamine users. Int J Legal Med 121:163-168.

Kochman LJ, Fornal CA, and Jacobs BL (2009) Suppression of hippocampal cell proliferation by short-term stimulant drug administration in adult rats. Eur $J$ Neurosci 29:2157-2165.

Kohno M, Morales AM, Ghahremani DG, Hellemann G, and London ED (2014) Risky decision making, prefrontal cortex, and mesocorticolimbic functional connectivity in methamphetamine dependence. JAMA Psychiatry 71:812-820.

Kuczenski R, Everall IP, Crews L, Adame A, Grant I, and Masliah E (2007) Escalating dose-multiple binge methamphetamine exposure results in degeneration of the neocortex and limbic system in the rat. Exp Neurol 207:42-51.

Kuczenski R, Segal DS, Cho AK, and Melega W (1995) Hippocampus norepinephrine, caudate dopamine and serotonin, and behavioral responses to the stereoisomers of amphetamine and methamphetamine. J Neurosci 15:1308-1317. 
Lake CR and Quirk RS (1984) CNS stimulants and the look-alike drugs. Psychiatr Clin North Am 7:689-701.

Lawton-Craddock A, Nixon SJ, and Tivis R (2003) Cognitive efficiency in stimulant abusers with and without alcohol dependence. Alcohol Clin Exp Res 27:457-464.

Le Cozannet R, Markou A, and Kuczenski R (2013) Extended-access, but not limitedaccess, methamphetamine self-administration induces behavioral and nucleus accumbens dopamine response changes in rats. Eur $J$ Neurosci 38:3487-3495.

Lee KW, Kim HC, Lee SY, and Jang CG (2011) Methamphetamine-sensitized mice are accompanied by memory impairment and reduction of N-methyl-d-aspartate receptor ligand binding in the prefrontal cortex and hippocampus. Neuroscience 178:101-107.

Lewin AH, Miller GM, and Gilmour B (2011) Trace amine-associated receptor 1 is a stereoselective binding site for compounds in the amphetamine class. Bioorg Med Chem 19:7044-7048

Lile JA, Charnigo RJ, and Nader MA (2013) The relative reinforcing strength of methamphetamine and D-amphetamine in monkeys self-administering cocaine. Behav Pharmacol 24:482-485 10.1097/FBP.1090b1013e3283644d3283644.

Lin LY, Di Stefano EW, Schmitz DA, Hsu L, Ellis SW, Lennard MS, Tucker GT, and Cho AK (1997) Oxidation of methamphetamine and methylenedioxymethamphetamine by CYP2D6. Drug Metab Dispos 25:1059-1064.

Liu B, Traini R, Killinger B, Schneider B, and Moszczynska A (2013) Overexpression of parkin in the rat nigrostriatal dopamine system protects against methamphetamine neurotoxicity. Exp Neurol 247:359-372.

London ED, Berman SM, Voytek B, Simon SL, Mandelkern MA, Monterosso J, Thompson PM, Brody AL, Geaga JA, Hong MS, et al. (2005) Cerebral metabolic dysfunction and impaired vigilance in recently abstinent methamphetamine abusers. Biol Psychiatry 58:770-778.

London ED (2016) Impulsivity, Stimulant Abuse, and Dopamine Receptor Signaling. Adv Pharmacol 76:67-84

London ED, Kohno M, Morales AM, and Ballard ME (2015) Chronic methamphetamine abuse and corticostriatal deficits revealed by neuroimaging. Brain Res $\mathbf{1 6 2 8}$ (Pt A):174-185.

London ED, Simon SL, Berman SM, Mandelkern MA, Lichtman AM, Bramen J, Shinn AK, Miotto K, Learn J, Dong Y, et al. (2004) Mood disturbances and regional cerebral metabolic abnormalities in recently abstinent methamphetamine abusers. Arch Gen Psychiatry 61:73-84.

Lopez RB, Onyemekwu C, Hart CL, Ochsner KN, and Kober H (2015) Boundary conditions of methamphetamine craving. Exp Clin Psychopharmacol 23:436-444.

Lorez H (1981) Fluorescence histochemistry indicates damage of striatal dopamine nerve terminals in rats after multiple doses of methamphetamine. Life Sci 28:911-916.

Lu P, Mamiya T, Lu L, Mouri A, Niwa M, Kim HC, Zou LB, Nagai T, Yamada K, Ikejima T, et al. (2010) Silibinin attenuates cognitive deficits and decreases of dopamine and serotonin induced by repeated methamphetamine treatment. Behav Brain Res 207:387-393.

Lundh H and Tunving K (1981) An extrapyramidal choreiform syndrome caused by amphetamine addiction. J Neurol Neurosurg Psychiatry 44:728-730.

Mack F and Bönisch H (1979) Dissociation constants and lipophilicity of catecholamines and related compounds. Naunyn Schmiedebergs Arch Pharmacol 310:1-9.

Mandyam CD, Wee S, Crawford EF, Eisch AJ, Richardson HN, and Koob GF (2008) Varied access to intravenous methamphetamine self-administration differentially alters adult hippocampal neurogenesis. Biol Psychiatry 64:958-965.

Mark KA, Soghomonian JJ, and Yamamoto BK (2004) High-dose methamphetamine acutely activates the striatonigral pathway to increase striatal glutamate and mediate long-term dopamine toxicity. $J$ Neurosci 24:11449-11456.

Martin WR, Sloan JW, Sapira JD, and Jasinski DR (1971) Physiologic, subjective, and behavioral effects of amphetamine, methamphetamine, ephedrine, phenmetrazine, and methylphenidate in man. Clin Pharmacol Ther 12:245-258.

Mash DC (2016) Excited Delirium and Sudden Death: A Syndromal Disorder at the Extreme End of the Neuropsychiatric Continuum. Front Physiol 7:435.

McCann UD, Wong DF, Yokoi F, Villemagne V, Dannals RF, and Ricaurte GA (1998) Reduced striatal dopamine transporter density in abstinent methamphetamine and methcathinone users: evidence from positron emission tomography studies with [11C]WIN-35,428. J Neurosci 18:8417-8422.

McGregor C, Srisurapanont M, Jittiwutikarn J, Laobhripatr S, Wongtan T, and White JM (2005) The nature, time course and severity of methamphetamine withdrawal. Addiction 100:1320-1329.

McKetin R and Mattick RP (1998) Attention and memory in illicit amphetamine users: comparison with non-drug-using controls. Drug Alcohol Depend 50:181-184.

McKetin R, McLaren J, Lubman DI, and Hides L (2006) The prevalence of psychotic symptoms among methamphetamine users. Addiction 101:1473-1478.

Mendelson J, Uemura N, Harris D, Nath RP, Fernandez E, Jacob, 3rd P, Everhart ET, and Jones RT (2006) Human pharmacology of the methamphetamine stereoisomers. Clin Pharmacol Ther 80:403-420.

Miller GM (2011) The emerging role of trace amine-associated receptor 1 in the functional regulation of monoamine transporters and dopaminergic activity. $J$ Neurochem 116:164-176.

Mirecki A, Fitzmaurice P, Ang L, Kalasinsky KS, Peretti FJ, Aiken SS, Wickham DJ, Sherwin A, Nobrega JN, Forman HJ, et al. (2004) Brain antioxidant systems in human methamphetamine users. J Neurochem 89:1396-1408.

Mizoguchi H, Ibi D, Takase F, Nagai T, Kamei H, Toth E, Sato J, Takuma K, and Yamada K (2011) Nicotine ameliorates impairment of working memory in methamphetamine-treated rats. Behav Brain Res 220:159-163.

Mizoguchi H and Yamada K (2011) Pharmacologic treatment with GABA(B) receptor agonist of methamphetamine-induced cognitive impairment in mice. Curr Neuropharmacol 9:109-112.

Monterosso JR, Ainslie G, Xu J, Cordova X, Domier CP, and London ED (2007) Frontoparietal cortical activity of methamphetamine-dependent and comparison subjects performing a delay discounting task. Hum Brain Mapp 28:383-393.

Monterosso JR, Aron AR, Cordova X, Xu J, and London ED (2005) Deficits in response inhibition associated with chronic methamphetamine abuse. Drug Alcohol Depend 79:273-277.
Mooney DJ, Hansen LK, Langer R, Vacanti JP, and Ingber DE (1994) Extracellular matrix controls tubulin monomer levels in hepatocytes by regulating protein turnover. Mol Biol Cell 5:1281-1288.

Moratalla R, Khairnar A, Simola N, Granado N, García-Montes JR, Porceddu PF, Tizabi Y, Costa G, and Morelli M (2015) Amphetamine-related drugs neurotoxicity in humans and in experimental animals: Main mechanisms. Prog Neurobiol DOI: 10.1016/j.pneurobio.2015.09.011 [published ahead of print].

Morgan JC, Winter WC, and Wooten GF (2004) Amphetamine-induced chorea in attention deficit-hyperactivity disorder. Mov Disord 19:840-842.

Morgan ME and Gibb JW (1980) Short-term and long-term effects of methamphetamine on biogenic amine metabolism in extra-striatal dopaminergic nuclei. Neuropharmacology 19:989-995.

Moszczynska A, Fitzmaurice P, Ang L, Kalasinsky KS, Schmunk GA, Peretti FJ, Aiken SS, Wickham DJ, and Kish SJ (2004) Why is parkinsonism not a feature of human methamphetamine users? Brain 127:363-370.

Moszczynska A, Flack A, Qiu P, Muotri AR, and Killinger BA (2015) Neurotoxic Methamphetamine Doses Increase LINE-1 Expression in the Neurogenic Zones of the Adult Rat Brain. Sci Rep 5:14356.

Moszczynska A, Turenne S, and Kish SJ (1998) Rat striatal levels of the antioxidant glutathione are decreased following binge administration of methamphetamine. Neurosci Lett 255:49-52.

Moszczynska A and Yamamoto BK (2011) Methamphetamine oxidatively damages parkin and decreases the activity of $26 \mathrm{~S}$ proteasome in vivo. $J$ Neurochem 116 1005-1017.

Nagai T, Takuma K, Dohniwa M, Ibi D, Mizoguchi H, Kamei H, Nabeshima T, and Yamada K (2007) Repeated methamphetamine treatment impairs spatial working memory in rats: reversal by clozapine but not haloperidol. Psychopharmacology (Berl) 194:21-32.

Nakagawa K, Vento MA, Ing MM, and Seto TB (2015) Racial disparities in methamphetamine-associated intracerebral hemorrhage. Neurology 84:995-1001.

Narendra D, Tanaka A, Suen DF, and Youle RJ (2008) Parkin is recruited selectively to impaired mitochondria and promotes their autophagy. J Cell Biol 183:795-803.

Nash JF and Yamamoto BK (1992) Methamphetamine neurotoxicity and striatal glutamate release: comparison to 3,4-methylenedioxymethamphetamine. Brain Res 581:237-243.

Nestor LJ, Ghahremani DG, Monterosso J, and London ED (2011) Prefrontal hypoactivation during cognitive control in early abstinent methamphetamine-dependent subjects. Psychiatry Res 194:287-295.

National Highway Traffic Safety Administration. Drug and Human Performance Fact Sheets: Methamphetamine (And Amphetamine). Retrieved from: https://one. nhtsa.gov/people/injury/research/job185drugs/methamphetamine.htm

Newton TF, De La Garza, 2nd R, Fong T, Chiang N, Holmes TH, Bloch DA, Anderson A, and Elkashef A (2005) A comprehensive assessment of the safety of intravenous methamphetamine administration during treatment with selegiline. Pharmaco Biochem Behav 82:704-711.

Noda Y, Mouri A, Ando Y, Waki Y, Yamada SN, Yoshimi A, Yamada K, Ozaki N, Wang $\mathrm{D}$, and Nabeshima T (2010) Galantamine ameliorates the impairment of recognition memory in mice repeatedly treated with methamphetamine: involvement of allosteric potentiation of nicotinic acetylcholine receptors and dopaminergic-ERK1/2 systems. Int $J$ Neuropsychopharmacol 13:1343-1354.

Nordahl TE, Salo R, and Leamon M (2003) Neuropsychological effects of chronic methamphetamine use on neurotransmitters and cognition: a review. J Neuropsychiatry Clin Neurosci 15:317-325.

Nordahl TE, Salo R, Natsuaki Y, Galloway GP, Waters C, Moore CD, Kile S, and Buonocore MH (2005) Methamphetamine users in sustained abstinence: a proton magnetic resonance spectroscopy study. Arch Gen Psychiatry 62:444-452.

Nordahl TE, Salo R, Possin K, Gibson DR, Flynn N, Leamon M, Galloway GP, Pfefferbaum A, Spielman DM, Adalsteinsson E, et al. (2002) Low N-acetyl-aspartate and high choline in the anterior cingulum of recently abstinent methamphetamine-dependent subjects: a preliminary proton MRS study. Magnetic resonance spectroscopy. Psychiatry Res 116 $43-52$.

North A, Swant J, Salvatore MF, Gamble-George J, Prins P, Butler B, Mittal MK, Heltsley R, Clark JT, and Khoshbouei H (2013) Chronic methamphetamine exposure produces a delayed, long-lasting memory deficit. Synapse 67:245-257.

Olarte-Sánchez CM, Amin E, Warburton EC, and Aggleton JP (2015) Perirhinal cortex lesions impair tests of object recognition memory but spare novelty detection. Eur J Neurosci 42:3117-3127.

O'Neill J, Tobias MC, Hudkins M, and London ED (2014) Glutamatergic neurometabolites during early abstinence from chronic methamphetamine abuse. Int $J$ Neuropsychopharmacol 18:18.

Orikabe L, Yamasue H, Inoue H, Takayanagi Y, Mozue Y, Sudo Y, Ishii T, Itokawa M, Suzuki M, Kurachi M, et al. (2011) Reduced amygdala and hippocampal volumes in patients with methamphetamine psychosis. Schizophr Res 132:183-189.

Ornstein TJ, Iddon JL, Baldacchino AM, Sahakian BJ, London M, Everitt BJ, and Robbins TW (2000) Profiles of cognitive dysfunction in chronic amphetamine and heroin abusers. Neuropsychopharmacology 23:113-126.

Park MJ, Lee SK, Lim MA, Chung HS, Cho SI, Jang CG, and Lee SM (2006) Effect of alpha-tocopherol and deferoxamine on methamphetamine-induced neurotoxicity. Brain Res 1109:176-182

Parsegian A, Glen, Jr WB, Lavin A, and See RE (2011) Methamphetamine selfadministration produces attentional set-shifting deficits and alters prefrontal cortical neurophysiology in rats. Biol Psychiatry 69:253-259.

Patrick KS, Straughn AB, Perkins JS, and González MA (2009) Evolution of stimulants to treat ADHD: transdermal methylphenidate. Hum Psychopharmacol 24:1-17.

Paulus MP, Hozack NE, Zauscher BE, Frank L, Brown GG, Braff DL, and Schuckit MA (2002) Behavioral and functional neuroimaging evidence for prefrontal dysfunction in methamphetamine-dependent subjects. Neuropsychopharmacology 26:53-63.

Perez-Reyes M, White WR, McDonald SA, Hicks RE, Jeffcoat AR, Hill JM, and Cook CE (1991) Clinical effects of daily methamphetamine administration. Clin $\mathrm{Neu}$ ropharmacol 14:352-358. 
Pike E, Stoops WW, and Rush CR (2016) Acute buspirone dosing enhances abuserelated subjective effects of oral methamphetamine. Pharmacol Biochem Behav 150-151:87-93.

Preston KL, Wagner GC, Schuster CR, and Seiden LS (1985) Long-term effects of repeated methylamphetamine administration on monoamine neurons in the rhesus monkey brain. Brain Res 338:243-248.

Pu C, Fisher JE, Cappon GD, and Vorhees CV (1994) The effects of amfonelic acid, a dopamine uptake inhibitor, on methamphetamine-induced dopaminergic terminal degeneration and astrocytic response in rat striatum. Brain Res 649:217-224.

Raineri M, Gonzalez B, Goitia B, Garcia-Rill E, Krasnova IN, Cadet JL, Urbano FJ, and Bisagno V (2012) Modafinil abrogates methamphetamine-induced neuroinflammation and apoptotic effects in the mouse striatum. PLoS One 7:e46599.

Recinto P, Samant AR, Chavez G, Kim A, Yuan CJ, Soleiman M, Grant Y, Edwards S, Wee S, Koob GF, et al. (2012) Levels of neural progenitors in the hippocampus predict memory impairment and relapse to drug seeking as a function of excessive methamphetamine self-administration. Neuropsychopharmacology 37:1275-1287.

Reichel CM, Gilstrap MG, Ramsey LA, and See RE (2014) Modafinil restores methamphetamine induced object-in-place memory deficits in rats independent of glutamate N-methyl-D-aspartate receptor expression. Drug Alcohol Depend 134: 115-122.

Reichel CM, Ramsey LA, Schwendt M, McGinty JF, and See RE (2012) Methamphetamineinduced changes in the object recognition memory circuit. Neuropharmacology 62:1119-1126.

Reichel CM, Schwendt M, McGinty JF, Olive MF, and See RE (2011) Loss of object recognition memory produced by extended access to methamphetamine selfadministration is reversed by positive allosteric modulation of metabotropic glutamate receptor 5. Neuropsychopharmacology 36:782-792.

Reichel CM and See RE (2012) Chronic modafinil effects on drug-seeking following methamphetamine self-administration in rats. Int $J$ Neuropsychopharmacol 15:919-929.

Rendell PG, Mazur M, and Henry JD (2009) Prospective memory impairment in former users of methamphetamine. Psychopharmacology (Berl) 203:609-616.

Ricaurte GA, Guillery RW, Seiden LS, Schuster CR, and Moore RY (1982) Dopamine nerve terminal degeneration produced by high doses of methylamphetamine in the rat brain. Brain Res 235:93-103.

Ricaurte GA, Schuster CR, and Seiden LS (1980) Long-term effects of repeated methylamphetamine administration on dopamine and serotonin neurons in the rat brain: a regional study. Brain Res 193:153-163.

Richards JR, Bretz SW, Johnson EB, Turnipseed SD, Brofeldt BT, and Derlet RW (1999a) Methamphetamine abuse and emergency department utilization. West $J$ Med 170:198-202.

Richards JR, Johnson EB, Stark RW, and Derlet RW (1999b) Methamphetamine abuse and rhabdomyolysis in the ED: a 5-year study. Am J Emerg Med 17:681-685

Rocher C and Gardier AM (2001) Effects of repeated systemic administration of d-Fenfluramine on serotonin and glutamate release in rat ventral hippocampus: com parison with methamphetamine using in vivo microdialysis. Naunyn Schmiedebergs Arch Pharmacol 363:422-428.

Rogasch NC, Daskalakis ZJ, and Fitzgerald PB (2015) Cortical inhibition of distinct mechanisms in the dorsolateral prefrontal cortex is related to working memory performance: a TMS-EEG study. Cortex 64:68-77.

Rogers JL, De Santis S, and See RE (2008) Extended methamphetamine selfadministration enhances reinstatement of drug seeking and impairs novel object recognition in rats. Psychopharmacology (Berl) 199:615-624.

Ross BM, Moszczynska A, Peretti FJ, Adams V, Schmunk GA, Kalasinsky KS, Ang L Mamalias N, Turenne SD, and Kish SJ (2002) Decreased activity of brain phospholipid metabolic enzymes in human users of cocaine and methamphetamine Drug Alcohol Depend 67:73-79.

Rungta RL, Choi HB, Tyson JR, Malik A, Dissing-Olesen L, Lin PJ, Cain SM, Cullis PR, Snutch TP, and MacVicar BA (2015) The cellular mechanisms of neuronal swelling underlying cytotoxic edema. Cell 161:610-621.

Rylander G (1969) Clinical and medico-criminological aspects of addiction to centra stimulating drugs, in Abuse of Central Stimulants, pp 251-273, Raven Press, New York.

Rylander G (1972) Psychoses and the punding and choreiform syndromes in addiction to central stimulant drugs. Psychiatr Neurol Neurochir 75:203-212.

Salo R, Fassbender C, Buonocore MH, and Ursu S (2013) Behavioral regulation in methamphetamine abusers: an fMRI study. Psychiatry Res 211:234-238.

Salo R, Nordahl TE, Galloway GP, Moore CD, Waters C, and Leamon MH (2009a) Drug abstinence and cognitive control in methamphetamine-dependent individuals. J Subst Abuse Treat 37:292-297.

Salo R, Nordahl TE, Buonocore MH, Natsuaki Y, Waters C, Moore CD, Galloway GP, and Leamon $\mathrm{MH}(2009 \mathrm{~b})$ Cognitive control and white matter callosal microstructure in methamphetamine-dependent subjects: a diffusion tensor imaging study. Biol Psychiatry 65:122-128

Salo R, Ursu S, Buonocore MH, Leamon MH, and Carter C (2009c) Impaired prefrontal cortical function and disrupted adaptive cognitive control in methamphetamine abusers: a functional magnetic resonance imaging study. Biol Psychiatry 65:706-709.

Salo R, Nordahl TE, Natsuaki Y, Leamon MH, Galloway GP, Waters C, Moore CD, and Buonocore $\mathrm{MH}$ (2007) Attentional control and brain metabolite levels in methamphetamine abusers. Biol Psychiatry 61:1272-1280.

Salo R, Nordahl TE, Possin K, Leamon M, Gibson DR, Galloway GP, Flynn NM, Henik A, Pfefferbaum A, and Sullivan EV (2002) Preliminary evidence of reduced cognitive inhibition in methamphetamine-dependent individuals. Psychiatry Res 111: $65-74$

Santillo MF (2014) Inhibition of monoamine oxidase (MAO) by $\alpha$-ethylphenethylamine and $\mathrm{N}, \alpha$-diethylphenethylamine, two compounds related to dietary supplements. Food Chem Toxicol 74:265-269.

Schröder N, O'Dell SJ, and Marshall JF (2003) Neurotoxic methamphetamine regimen severely impairs recognition memory in rats. Synapse 49:89-96.

Schwartz DL, Mitchell AD, Lahna DL, Luber HS, Huckans MS, Mitchell SH, and Hoffman WF (2010) Global and local morphometric differences in recently abstinent methamphetamine-dependent individuals. Neuroimage 50:1392-1401.
Scofield MD, Trantham-Davidson H, Schwendt M, Leong KC, Peters J, See RE, and Reichel CM (2015) Failure to Recognize Novelty after Extended Methamphetamine Self-Administration Results from Loss of Long-Term Depression in the Perirhinal Cortex. Neuropsychopharmacology 40:2526-2535

Scott JC, Woods SP, Matt GE, Meyer RA, Heaton RK, Atkinson JH, and Grant I (2007) Neurocognitive effects of methamphetamine: a critical review and metaanalysis. Neuropsychol Rev 17:275-297.

Seiden LS, Commins DL, Vosmer G, Axt K, and Marek G (1988) Neurotoxicity in dopamine and 5-hydroxytryptamine terminal fields: a regional analysis in nigrostriatal and mesolimbic projections. Ann N Y Acad Sci 537:161-172.

Seiden LS and Sabol KE (1996) Methamphetamine and methylenedioxymethamphetamine neurotoxicity: possible mechanisms of cell destruction. NIDA Res Monogr 163: 251-276.

Sekine Y, Minabe Y, Kawai M, Suzuki K, Iyo M, Isoda H, Sakahara H, Ashby, Jr CR, Takei N, and Mori N (2002) Metabolite alterations in basal ganglia associated with methamphetamine-related psychiatric symptoms. A proton MRS study. Neuropsychopharmacology 27:453-461.

Sekine Y, Minabe Y, Ouchi Y, Takei N, Iyo M, Nakamura K, Suzuki K, Tsukada H, Okada H, Yoshikawa E, et al. (2003) Association of dopamine transporter loss in the orbitofrontal and dorsolateral prefrontal cortices with methamphetaminerelated psychiatric symptoms. Am J Psychiatry 160:1699-1701.

Sekine Y, Ouchi Y, Sugihara G, Takei N, Yoshikawa E, Nakamura K, Iwata Y, Tsuchiya KJ, Suda S, Suzuki K, et al. (2008) Methamphetamine causes microglial activation in the brains of human abusers. J Neurosci 28:5756-5761.

Sekine Y, Ouchi Y, Takei N, Yoshikawa E, Nakamura K, Futatsubashi M, Okada H Minabe Y, Suzuki K, Iwata Y, et al. (2006) Brain serotonin transporter density and aggression in abstinent methamphetamine abusers. Arch Gen Psychiatry 63:90-100.

Sevak RJ, Stoops WW, Hays LR, and Rush CR (2009) Discriminative stimulus and subjectrated effects of methamphetamine, d-amphetamine, methylphenidate, and triazolam in methamphetamine-trained humans. J Pharmacol Exp Ther 328:1007-1018.

Sharma HS and Kiyatkin EA (2009) Rapid morphological brain abnormalities during acute methamphetamine intoxication in the rat: an experimental study using light and electron microscopy. $J$ Chem Neuroanat 37:18-32.

Shiba T, Yamato M, Kudo W, Watanabe T, Utsumi H, and Yamada K (2011) In vivo imaging of mitochondrial function in methamphetamine-treated rats. Neuroimage 57:866-872.

Shioda K, Nisijima K, Yoshino T, and Kato S (2010) Effect of risperidone on acute methamphetamine-induced hyperthermia in rats. Drug Alcohol Depend 111:241-249.

Siegel JA, Craytor MJ, and Raber J (2010) Long-term effects of methamphetamine exposure on cognitive function and muscarinic acetylcholine receptor levels in mice. Behav Pharmacol 21:602-614.

Silbersweig DA, Stern E, Frith C, Cahill C, Holmes A, Grootoonk S, Seaward J, McKenna P, Chua SE, Schnorr L, et al. (1995) A functional neuroanatomy of hallucinations in schizophrenia. Nature 378:176-179.

Silva CD, Neves AF, Dias AI, Freitas HJ, Mendes SM, Pita I, Viana SD, de Oliveira PA, Cunha RA, Fontes Ribeiro CA, et al. (2014) A single neurotoxic dose of methamphetamine induces a long-lasting depressive-like behaviour in mice. $\mathrm{Neu}$ rotox Res 25:295-304.

Sim T, Simon SL, Domier CP, Richardson K, Rawson RA, and Ling W (2002) Cognitive deficits among methamphetamine users with attention deficit hyperactivity disorder symptomatology. J Addict Dis 21:75-89.

Simões PF, Silva AP, Pereira FC, Marques E, Grade S, Milhazes N, Borges F, Ribeiro CF, and Macedo TR (2007) Methamphetamine induces alterations on hippocampal NMDA and AMPA receptor subunit levels and impairs spatial working memory. Neuroscience 150:433-441.

Simon SL, Dean AC, Cordova X, Monterosso JR, and London ED (2010) Methamphetamine dependence and neuropsychological functioning: evaluating change during early abstinence. J Stud Alcohol Drugs 71:335-344.

Simon SL, Domier C, Carnell J, Brethen P, Rawson R, and Ling W (2000) Cognitive impairment in individuals currently using methamphetamine. Am $J$ Addict $\mathbf{9}$ $222-231$

Simon SL, Richardson K, Dacey J, Glynn S, Domier CP, Rawson RA, and Ling W (2002) A comparison of patterns of methamphetamine and cocaine use. J Addict Dis 21:35-44.

Smith DE (1979) Amphetamine use, misuse, and abuse, in Proceedings of the National Amphetamine Conference, 1978, San Francisco, California, Boston: G.K. Hall, Medical Publications Division.

Smith ML, Nichols DC, Underwood P, Fuller Z, Moser MA, Flegel R, Gorelick DA, Newmeyer MN, Concheiro M, and Huestis MA (2014) Methamphetamine and amphetamine isomer concentrations in human urine following controlled Vicks VapoInhaler administration. J Anal Toxicol 38:524-527.

Sonsalla PK, Gibb JW, and Hanson GR (1986) Roles of D1 and D2 dopamine receptor subtypes in mediating the methamphetamine-induced changes in monoamine systems. J Pharmacol Exp Ther 238:932-937.

Sperling LS and Horowitz JL (1994) Methamphetamine-induced choreoathetosis and rhabdomyolysis. Ann Intern Med 121:986.

Stadlin A, Lau JW, and Szeto YK (1998) A selective regional response of cultured astrocytes to methamphetamine. Ann N Y Acad Sci 844:108-121.

Substance Abuse and Mental Health Services Administration (2016) Key substance use and mental health indicators in the United States: results from the $2015 \mathrm{Na}$ tional Survey on Drug Use and Health. HHS Publication No. SMA 16-4984, NSDUH Series $H$-51, Rockville, MD.

Sulzer D, Chen TK, Lau YY, Kristensen H, Rayport S, and Ewing A (1995) Amphetamine redistributes dopamine from synaptic vesicles to the cytosol and promotes reverse transport. $J$ Neurosci 15:4102-4108.

Sulzer D and Rayport S (1990) Amphetamine and other psychostimulants reduce pH gradients in midbrain dopaminergic neurons and chromaffin granules: a mechanism of action. Neuron 5:797-808.

Suzuki O, Hattori H, Asano M, Oya M, and Katsumata Y (1980) Inhibition of monoamine oxidase by d-methamphetamine. Biochem Pharmacol 29:2071-2073. 
Tabibnia G, Monterosso JR, Baicy K, Aron AR, Poldrack RA, Chakrapani S, Lee B, and London ED (2011) Different forms of self-control share a neurocognitive substrate. J Neurosci 31:4805-4810.

Teuchert-Noodt G, Dawirs RR, and Hildebrandt K (2000) Adult treatment with methamphetamine transiently decreases dentate granule cell proliferation in the gerbil hippocampus. J Neural Transm (Vienna) 107:133-143.

Thanos PK, Kim R, Delis F, Ananth M, Chachati G, Rocco MJ, Masad I, Muniz JA, Grant SC, Gold MS, et al. (2016) Chronic Methamphetamine Effects on Brain Structure and Function in Rats. PLoS One 11:e0155457.

Thomas DM, Walker PD, Benjamins JA, Geddes TJ, and Kuhn DM (2004) Meth amphetamine neurotoxicity in dopamine nerve endings of the striatum is associated with microglial activation. J Pharmacol Exp Ther 311:1-7.

Thompson PM, Hayashi KM, Simon SL, Geaga JA, Hong MS, Sui Y, Lee JY, Toga AW, Ling W, and London ED (2004) Structural abnormalities in the brains of human subjects who use methamphetamine. $J$ Neurosci 24:6028-6036.

Tobias MC, O'Neill J, Hudkins M, Bartzokis G, Dean AC, and London ED (2010) White-matter abnormalities in brain during early abstinence from methamphetamine abuse. Psychopharmacology (Berl) 209:13-24.

Todd G, Noyes C, Flavel SC, Della Vedova CB, Spyropoulos P, Chatterton B, Berg D and White JM (2013) Illicit stimulant use is associated with abnormal substantia nigra morphology in humans. PLoS One 8:e56438.

Todd G, Pearson-Dennett V, Wilcox RA, Chau MT, Thoirs K, Thewlis D, Vogel AP, and White JM (2016) Adults with a history of illicit amphetamine use exhibit abnormal substantia nigra morphology and parkinsonism. Parkinsonism Relat Disord 25:27-32.

Tokunaga I, Ishigami A, Kubo S, Gotohda T, and Kitamura O (2008) The peroxidative DNA damage and apoptosis in methamphetamine-treated rat brain. $J$ Med Invest 55:241-245.

Tong J, Fitzmaurice P, Furukawa Y, Schmunk GA, Wickham DJ, Ang LC, Sherwin A, McCluskey T, Boileau I, and Kish SJ (2014) Is brain gliosis a characteristic of chronic methamphetamine use in the human? Neurobiol Dis 67:107-118.

Tong J, Ross BM, Schmunk GA, Peretti FJ, Kalasinsky KS, Furukawa Y, Ang LC, Aiken SS, Wickham DJ, and Kish S.J (2003) Decreased striatal dopamine D1 receptor-stimulated adenylyl cyclase activity in human methamphetamine users. Am J Psychiatry 160:896-903.

Uhlmann A, Fouche JP, Lederer K, Meintjes EM, Wilson D, and Stein DJ (2016) White matter microstructure and impulsivity in methamphetamine dependence with and without a history of psychosis. Hum Brain Mapp 37:2055-2067.

Ujike H, Katsu T, Okahisa Y, Takaki M, Kodama M, Inada T, Uchimura N, Yamada M, Iwata N, Sora I, et al. (2009) Genetic variants of D2 but not D3 or D4 dopamine receptor gene are associated with rapid onset and poor prognosis of methamphetamine psychosis. Prog Neuropsychopharmacol Biol Psychiatry 33:625-629.

Ujike H, Onoue T, Akiyama K, Hamamura T, and Otsuki S (1989) Effects of selective D-1 and D-2 dopamine antagonists on development of methamphetamine-induced behavioral sensitization. Psychopharmacology (Berl) 98:89-92.

United Nations Office on Drugs and Crime (2015). World Drug Report, United Nations publication, Sales No. E.15.XI.6.

Volkow ND, Chang L, Wang GJ, Fowler JS, Ding YS, Sedler M, Logan J, Francesch D, Gatley J, Hitzemann R, et al. (2001a) Low level of brain dopamine D2 receptor in methamphetamine abusers: association with metabolism in the orbitofrontal cortex. Am J Psychiatry 158:2015-2021.

Volkow ND, Chang L, Wang GJ, Fowler JS, Franceschi D, Sedler MJ, Gatley SJ, Hitzemann R, Ding YS, Wong C, et al. (2001b) Higher cortical and lower subcortical metabolism in detoxified methamphetamine abusers. Am $J$ Psychiatry 158: 383-389.

Volkow ND, Chang L, Wang GJ, Fowler JS, Franceschi D, Sedler M, Gatley SJ, Miller E, Hitzemann R, Ding YS, et al. (2001c) Loss of dopamine transporters in methamphetamine abusers recovers with protracted abstinence. $J$ Neurosci 21 9414-9418.

Volkow ND, Chang L, Wang GJ, Fowler JS, Leonido-Yee M, Franceschi D, Sedler MJ, Gatley SJ, Hitzemann R, Ding YS, et al. (2001d) Association of dopamine transporter reduction with psychomotor impairment in methamphetamine abusers. $\mathrm{Am}$ $J$ Psychiatry 158:377-382.

Volkow ND, Wang GJ, Smith L, Fowler JS, Telang F, Logan J, and Tomasi D (2015) Recovery of dopamine transporters with methamphetamine detoxification is not linked to changes in dopamine release. Neuroimage 121:20-28.

Völlm BA, De Araujo IE, Cowen PJ, Rolls ET, Kringelbach ML, Smith KA and Matthews PM (2004) Methamphetamine activates reward circuitry in drug naive human subjects. Neuropsychopharmacology 29(9):1715.
Volz TJ, Hanson GR, and Fleckenstein AE (2007) The role of the plasmalemmal dopamine and vesicular monoamine transporters in methamphetamine-induced dopaminergic deficits. $J$ Neurochem 101:883-888.

Vorhees CV, Skelton MR, Grace CE, Schaefer TL, Graham DL, Braun AA and Williams MT (2009) Effects of (+)-methamphetamine on path integration and spatial learning, but not locomotor activity or acoustic startle, align with the stress hyporesponsive period in rats. Int J Dev Neurosci 27:289-298.

Wagner GC, Ricaurte GA, Seiden LS, Schuster CR, Miller RJ, and Westley J (1980) Long-lasting depletions of striatal dopamine and loss of dopamine uptake sites following repeated administration of methamphetamine. Brain Res 181:151-160.

Wallace TL, Gudelsky GA, and Vorhees CV (1999) Methamphetamine-induced neurotoxicity alters locomotor activity, stereotypic behavior, and stimulated dopamine release in the rat. $J$ Neurosci 19:9141-9148.

Wang G, Shi J, Chen N, Xu L, Li J, Li P, Sun Y, and Lu L (2013) Effects of length of abstinence on decision-making and craving in methamphetamine abusers. PLoS One 8:e68791.

Wang GJ, Smith L, Volkow ND, Telang F, Logan J, Tomasi D, Wong CT, Hoffman W, Jayne M, Alia-Klein N, et al. (2012) Decreased dopamine activity predicts relapse in methamphetamine abusers. Mol Psychiatry 17:918-925.

Wang GJ, Volkow ND, Chang L, Miller E, Sedler M, Hitzemann R, Zhu W, Logan J, $\mathrm{Ma} \mathrm{Y}$, and Fowler JS (2004) Partial recovery of brain metabolism in methamphetamine abusers after protracted abstinence. Am J Psychiatry 161:242-248.

Warren MW, Kobeissy FH, Liu MC, Hayes RL, Gold MS, and Wang KK (2005) Concurrent calpain and caspase-3 mediated proteolysis of alpha II-spectrin and tau in rat brain after methamphetamine exposure: a similar profile to traumatic brain injury. Life Sci 78:301-309.

Warren MW, Larner SF, Kobeissy FH, Brezing CA, Jeung JA, Hayes RL, Gold MS, and Wang KK (2007) Calpain and caspase proteolytic markers co-localize with rat cortical neurons after exposure to methamphetamine and MDMA. Acta Neuropathol 114:277-286.

Weafer J, Mitchell SH, and de Wit H (2014) Recent translational findings on impulsivity in relation to drug abuse. Curr Addict Rep 1:289-300.

Weber E, Blackstone K, Iudicello JE, Morgan EE, Grant I, Moore DJ, and Woods SP Translational Methamphetamine AIDS Research Center (TMARC) Group (2012) Neurocognitive deficits are associated with unemployment in chronic methamphetamine users. Drug Alcohol Depend 125:146-153.

Wilson JM, Kalasinsky KS, Levey AI, Bergeron C, Reiber G, Anthony RM, Schmunk GA, Shannak K, Haycock JW, and Kish SJ (1996) Striatal dopamine nerve terminal markers in human, chronic methamphetamine users. Nat Med 2:699-703.

Winhusen TM, Somoza EC, Lewis DF, Kropp FB, Horigian VE, and Adinoff B. Frontal systems deficits in stimulant-dependent patients: evidence of pre-illness dysfunction and relationship to treatment response. Drug Alcohol Depend (2013) 127:94-100. doi: 10.1016/j.drugalcdep.2012.06.017

Woolverton WL, Ricaurte GA, Forno LS, and Seiden LS (1989) Long-term effects of chronic methamphetamine administration in rhesus monkeys. Brain Res 486:73-78.

$\mathrm{Xu}$ W, Zhu JP, and Angulo JA (2005) Induction of striatal pre- and postsynaptic damage by methamphetamine requires the dopamine receptors. Synapse 58:110-121.

Yamamoto BK, Moszczynska A, and Gudelsky GA (2010) Amphetamine toxicities: classical and emerging mechanisms. Ann N Y Acad Sci 1187:101-121.

Yamamoto BK and Zhu W (1998) The effects of methamphetamine on the production of free radicals and oxidative stress. J Pharmacol Exp Ther 287:107-114.

Yu J, Wang J, Cadet JL, and Angulo JA (2004) Histological evidence supporting a role for the striatal neurokinin-1 receptor in methamphetamine-induced neurotoxicity in the mouse brain. Brain Res 1007:124-131.

Yuan J, Liu XD, Han M, Lv RB, Wang YK, Zhang GM, and Li Y (2017) Comparison of striatal dopamine transporter levels in chronic heroin-dependent and methamphetaminedependent subjects. Addict Biol 22:229-234.

Zaczek R, Culp S, and De Souza EB (1991) Interactions of [3H]amphetamine with rat brain synaptosomes. II. Active transport. J Pharmacol Exp Ther 257:830-835.

Zhu JP, Xu W, and Angulo JA (2005) Disparity in the temporal appearance of methamphetamine-induced apoptosis and depletion of dopamine terminal markers in the striatum of mice. Brain Res 1049:171-181.

Zweben JE, Cohen JB, Christian D, Galloway GP, Salinardi M, Parent D, and Iguchi M; Methamphetamine Treatment Project (2004) Psychiatric symptoms in methamphetamine users. Am J Addict 13:181-190.

Address correspondence to: Anna Moszczynska, Department of Pharmaceutical Sciences, Wayne State University, 259 Mack Avenue, Detroit, MI. E-mail: amosz@wayne.edu 